\title{
LA AUTONOMÍA DE LA VOLUNTAD EN LA LEGISLACIÓN CHILENA DE DERECHO INTERNACIONAL PRIVADO
}

\author{
PARTY AUTONOMY IN CHILEAN PRIVATE INTERNATIONAL LAW
}

\section{María Ignacia Vial Undurraga*}

\begin{abstract}
RESUMEN: La autonomía de la voluntad en los contratos internacionales, entendida como el derecho de las partes para elegir la ley aplicable a un contrato, es ampliamente aceptada a nivel mundial y considerada como perteneciente al "cuerpo común de los sistemas legales". Este artículo muestra, sin embargo, que esta autonomía no está claramente aceptada en Chile a pesar de ser ampliamente utilizada en el país. En efecto, los tribunales nacionales vacilan en aceptar la validez de las cláusulas de elección de ley extranjera contenidas en los contratos que se cumplen en Chile debido al fuerte territorialismo de la ley chilena. Por ello, se concluye que es necesario modificar la legislación vigente para regular el ejercicio de la autonomía de la voluntad y eliminar la incerteza jurídica respecto de la eficacia de estas cláusulas en Chile. Esta modificación serviría además para actualizar, perfeccionar y armonizar las normas de conflicto chilenas sobre contratos con aquellas de la mayoría de los países.
\end{abstract}

Palabras clave: Autonomía de la voluntad, contratos internacionales, cláusulas de elección de ley, derecho internacional privado chileno.

ABSTRACT: Party autonomy in international contracts, understood as the right of the parties to choose the governing law of a contract, is widely accepted worldwide and said to belong to the "common core of the legal systems". This paper shows, however, that autonomy is not clearly statutorily accepted in Chile, though being widely practiced in the country. In fact, national courts vacillate as to upholding choice of foreign law clauses in international contracts performed in Chile due to the strong territorialism of Chilean law. Thus, the amendment of this law in order to consolidate autonomy is needed to secure the validity of these clauses and to eradicate juridical uncertainty about their efficacy. Further, it will help to update, perfect and harmonize Chilean conflict rules with those of most countries.

Key words: Party autonomy, international contracts, choice of law clauses, Chilean private international law.

\section{EL PRINCIPIO DE LA AUTONOMÍA DE LA VOLUNTAD: CONCEPTO Y JUSTIFICACIÓN}

\subsection{El concepto de autonomía de la voluntad en el Derecho InTERNACIONAL PRIVAdo}

La autonomía de la voluntad en el Derecho Internacional Privado se define como el derecho de las partes para elegir la ley que gobierna un contrato ${ }^{1}$. Esto es, su facultad

\footnotetext{
* Licenciada en Ciencias Jurídicas, Pontificia Universidad Católica de Chile; Doctora en Derecho, King’s College London. Profesora de Derecho Internacional Privado de la Pontificia Universidad Católica de Chile y de la Universidad de los Andes. Correo electrónico: mivial@uandes.cl.

1 Alguna doctrina de lengua española usa el término "autonomía conflictual” para designar a esta autonomía,
} 
de *determinar la ley que es causa causans del contrato $^{2}$; la ley que provee las normas que determinan la existencia, validez sustancial y los efectos del contrato y también aquellas normas que las partes no pueden desplazar convencionalmente; y finalmente, la ley que gobierna también la elección misma de ley estableciendo los requisitos para realizarla y regulando sus efectos.

Esta autonomía de la voluntad se distingue de la incorporación por referencia de una ley extranjera en un contrato. En la autonomía, las partes someten el contrato a la ley elegida, y ella pasa a ser la ley que lo gobierna o su "proper law", desplazando otras leyes que, sin mediar la elección, lo gobernarían. En la incorporación, las partes incorporan las normas de la ley extranjera como cláusulas del contrato, quedando la validez de estas cláusulas y el contrato mismo gobernados por una ley diferente ya sea elegida por las partes o determinada por las normas de conflicto del foro ${ }^{3}$.

Esta autonomía también se diferencia de la libertad contractual de derecho interno, la que permite a las partes desplazar algunas normas subsidiarias de la ley que gobierna el contrato o elaborar ciertas normas dispositivas que se aplicarán a él pero siempre, dentro de los límites y sujetas a los requisitos establecidos por la ley que gobierna al contrato ${ }^{4}$.

La autonomía de la voluntad, como principio del Derecho Internacional Privado se desarrolló principalmente a mediados del siglo 19 y $20^{5}$. Si bien, su aceptación fue inicialmente controvertida en algunos países ${ }^{6}$, es hoy tan universal que se la considera como perteneciente al "cuerpo común de los sistemas legales" ser universalmente aceptada en Latinoamérica. Así, por ejemplo, es persistentemente rechazada en Brasil $^{8}$ y Uruguay ${ }^{9}$; es aceptada como una práctica legal en Argentina ${ }^{10}$ y Chile $^{11}$, países que no tienen normas generales que la regulen, y solo ha sido recientemente regulada en las leyes de México ${ }^{12}$, Perú ${ }^{13}$ y Venezuela ${ }^{14}$.

aunque el término más universalmente aceptado es el de autonomía de la voluntad de las partes, ver, por ejemplo: Boggiano (2000) p. 677; Fernández (2004) pp. 35-78; Goldschmidt (1984) pp. 711-720; HernánDeZ-Bretón (2003) p. 441-471; Leible (2011) pp. 214-233.

2 Nygh (1999) p. 1.

3 Lando (1985) p. 256; Plender y Wilderspin (2009) pp. 135-136.

${ }^{4}$ NyGh (1999) p. 1.

5 Lando (1985) pp. 256-284; Nygh (1999) pp. 3-14; Rabel (1947) pp. 368-376. Para el desarrollo europeo ver Informe Giuliano y Lagarde (1980) pp. 15-16 y Plender y Wilderspin (2009) pp. 131-134; Rühl (2007) pp. 155-158.

${ }_{6}^{6}$ Lando (1976) pp. 14-33, (1985) pp. 256-284; NyGH (1999) pp. 8-13; Scoles et al. (2004) pp. 952-954.

7 Lando (1976) p. 33, (1985) p. 237; Nygh (1999) pp. 13-14. Informe Giuliano y Lagarde (1980) pp. 1518; Plender y Wilderspin (2009) p. 131. Para el actual desarrollo mundial ver Estudio Hague Conference On Private International LaW (2009) p. 4.

8 Art 9 Ley de Introducción al Código Civil Brasileño, de 1942.

9 Art 2399 Código Civil del Uruguay.

10 Boggiano (1983) p. 473; Kaller (1995) p. 351.

11 Ver infra 2.1. B.

12 Art. 13 V Código Civil Federal Mexicano, del 2000; art. 13 V Código Civil para el Distrito Federal Mexicano, del 2000

13 Art. 2095 Código Civil Peruano, de 1984.

14 Art. 29 Ley de Derecho Internacional Privado Venezolana, de 1998. 
Varios instrumentos internacionales han contribuido a la aceptación universal de este principio ${ }^{15}$. Entre ellos, el más importante es el Convenio sobre la Ley Aplicable a las Obligaciones Contractuales, Roma 19-VI-1980 (el "Convenio de Roma"). Este Convenio sancionó legislativamente la autonomía de la voluntad y unificó el derecho europeo relativo a la ley aplicable a los contratos, y ha sido transformado en un Reglamento vigente en toda la Unión Europea, Reglamento (CE) No 593/2008 del Parlamento Europeo y del Consejo de 17 de junio del 2008 Sobre Ley Aplicable a las Obligaciones Contractuales (Roma I) (el "Reglamento Roma I"). Además este Convenio sirvió de modelo a la Convención Interamericana sobre Derecho Aplicable a los Contratos Internacionales (CIDIP V), México D.F. 17-III-1994 (la "Convención de México") que pretendió sancionar legislativamente la autonomía en los países de Latinoamérica aunque, por ahora, con escasos resultados ${ }^{16}$.

\subsection{LA JUSTIFICACiÓN DE LA AUTONOMÍA DE LA VOLUNTAD}

La autonomía de la voluntad se justifica con variadas razones:

Principalmente se argumenta que las partes necesitan libertad para contratar en el ámbito internacional y que la autonomía reconoce y garantiza esta libertad ${ }^{17}$. Se acepta que las partes pueden tener motivos válidos y legítimos para elegir una ley determinada para gobernar su contrato; por ejemplo, querer elegir una ley bien desarrollada y adecuada para él, o una que conocen bien, o una que han usado en un negocio anterior o en otro contrato ${ }^{18}$. Se afirma así que la autonomía debe ser aceptada aunque sujeta a ciertos límites para garantizar los valores fundamentales del Estado y la protección de la parte más débil del contrato.

También se expone que la naturaleza particular de los contratos internacionales y de los problemas que suscitan, exigen un tratamiento legal especial para evitar que sean gobernados por leyes que no les acomoden bien $^{19}$. Se reconoce que las partes pueden usar la autonomía como una herramienta efectiva para excluir una ley inapropiada que, de otro modo, gobernaría el contrato; o excluir la ley nacional de una o ambas partes y elegir otra ley que consideran "neutra" o para elegir, de entre un vasto número de leyes, la que les parezca más conveniente para gobernar la totalidad o una parte específica de su contrato ${ }^{20}$. De este modo, la flexibilidad que da la autonomía es un antídoto contra la rigidez de las normas de conflicto nacionales que pueden establecer una ley inapropiada para gobernar un contrato en particular ${ }^{21}$.

La autonomía se defiende también por aumentar la certeza y predictibilidad de la ley que gobierna a los contratos internacionales ${ }^{22}$. En efecto, la ley que gobierna estos contra-

\footnotetext{
15 Informe Giuliano y Lagarde (1980) p. 16; Plender y Widerspin (2009) p. 131.

16 La Convención fue suscrita por Bolivia, Brasil, México, Uruguay y Venezuela, pero solo ha sido ratificada por México y Venezuela.

17 Leible (2011) p. 217; Nygh (1999) p. 2.

18 Lando (1985) p. 285; Leible (2011) p. 217.

19 Kassis (1993) pp. 194-195.

20 Leible (2011) pp. 217-218; MaYer (2001) pp. 471-472.

21 Kassis (1993) p. 190.

22 Leible (2011) p. 218; Nygh (1999) pp. 2-3; Plender y Wilderspin (2009) p. 132.
} 
tos es difícil de prever ya que ellos están conectados a diversas legislaciones nacionales, con normas de conflicto propias para determinar la ley que los gobierna, siendo todas estas normas potencialmente aplicables a estos contratos e ignorándose a priori cuál de todas ellas aplicará el tribunal llamado a resolver las disputas que surjan de ellos. Esta incertidumbre puede, sin embargo, disminuirse considerablemente con una elección de ley si las jurisdicciones conectadas al contrato aceptan la autonomía de la voluntad. Además, con esta elección las partes pueden fijar la ley reguladora del contrato de antemano, mientras este se está negociando ${ }^{23}$.

Finalmente se argumenta que la autonomía de la voluntad permite y facilita el comercio internacional y puede ser considerada como una base fundamental de una economía de mercado ${ }^{24}$. Esto porque, en el comercio internacional las partes compiten no solo respecto de los bienes y servicios sino también respecto del sistema legal que ofrecen ${ }^{25}$. Así, una estructura legal adecuada para los contratos internacionales promueve el comercio internacional y facilita el intercambio de bienes entre países ${ }^{26}$. Se insiste entonces que la autonomía de la voluntad contribuye a esta adecuada estructura legal al garantizar la libertad contractual y una ley adecuada y predecible para gobernar los contratos internacionales.

\subsection{LA AUTONOMÍA DE LA VOLUNTAD Y LA ELECCIÓN DE FORO}

Las elecciones de foro son válidas en muchas jurisdicciones ${ }^{27}$ y se justifican con las mismas razones dadas para las elecciones de $l e y^{28}$. En un sentido amplio, puede entenderse que el término autonomía de la voluntad también comprende estas elecciones; no obstante, el derecho comparado considera las elecciones de ley y de foro como asuntos separados gobernados por distintas normas de conflicto ${ }^{29}$; por ello en este trabajo, el término autonomía de la voluntad se usa exclusivamente para designar la elección de ley.

Sin embargo, debe reconocerse que las elecciones de ley y foro están estrechamente relacionadas entre sí puesto que la eficacia de una elección de ley depende fundamentalmente de la ley del foro en donde se entable la acción; de ahí que sea práctica frecuente que se incluyan ambas elecciones en los contratos internacionales de modo de garantizar que la autonomía sea aceptada. Por otra parte, a veces, los jueces pueden establecer que la elección de un cierto foro es un indicador de una elección tácita de la ley de ese foro o considerarla como una presunción de la intención de las partes de aplicarla ${ }^{30}$.

\footnotetext{
23 LANDo (1976) p. 84.

24 Nygh (1999) p. 2; Plender y Wilderspin (2001) p. 88.

25 LANDo (1985) p. 285.

26 Conforme a una encuesta realizada por la Cámara de Comercio Internacional, ICC en el año 2003; 41\% de las compañías encuestadas se desistió de continuar una negociación y de celebrar un contrato internacional a causa de la incertidumbre respecto del tribunal que resolvería las disputas originadas por el contrato o la ley que se le aplicaría. Este porcentaje subió al $47 \%$ respecto de negociaciones con compañías sudamericanas. Disponible en: http://www.output.dk/survey/report.asp [fecha de consulta: 15-VIII-2003].

27 Nygh (1999) pp. 15-24; Scoles et al. (2004) pp. 478-481, 952-954.

28 SCOLEs et al. (2004) p. 478.

29 Nygh (1999) pp. 15-24.

30 Informe Giuliano y Lagarde (1980) p. 17; Lando (1985) p. 312; Scoles et al. (2004) pp. 950-951.
} 


\section{LA AUTONOMÍA DE LA VOLUNTAD EN LA LEGISLACIÓN CHILENA ${ }^{31}$}

\subsection{LAS NORMAS CHILENAS RELATIVAS A CONTRATOS INTERNACIONALES}

\section{A. Territorialismo y libertad contractual en la legislación chilena}

Las normas de conflicto chilenas relativas a contratos están inspiradas en dos principios de difícil reconciliación: el principio de territorialidad de la ley y el de libertad contractual. La prevalencia que se ha dado a alguno de estos principios en la interpretación de estas normas ha influido en la aceptación de la autonomía de la voluntad en los tribunales chilenos. Así, cuando estas normas han sido interpretadas como inspiradas por el territorialismo, las cláusulas de elección de ley extranjera en contratos celebrados o cumplideros en Chile han sido rechazadas judicialmente ${ }^{32}$; y cuando han sido interpretadas como consagrando una amplia libertad contractual, estas cláusulas han sido aceptadas con mínimas limitaciones ${ }^{33}$. A continuación se desarrollan algunas breves ideas respecto de estos dos principios para después analizar en detalle la aceptación de la autonomía de la voluntad en la legislación chilena.

El principio de territorialidad es el principio fundante del Derecho Internacional Privado chileno ${ }^{34}$. Como consecuencia, la ley chilena obliga a cualquiera que resida en o esté físicamente presente en el país, incluso como transeúnte ${ }^{35}$ como asimismo, a todo acto ejecutado y todo bien ubicado en Chile ${ }^{36}$. De este modo, el principio de territorialidad es absoluto y conlleva dos principios tácitos: a) que la ley chilena obliga solo en Chile y carece de obligatoriedad fuera del país ${ }^{37}$ y b) que la ley extranjera no obliga en Chile a menos de que la ley chilena la declare aplicable ${ }^{38}$.

El territorialismo de la ley chilena se refleja en la escasez de sus normas de conflicto y en el hecho de que ellas son generalmente unilaterales, es decir, determinan cuándo debe aplicarse la ley chilena sin indicar qué ley aplicar cuando esta resulta inaplicable ${ }^{39}$. De este modo, los jueces chilenos se enfrentan a numerosos vacíos legislativos que deben llenar deduciendo principios generales de derecho de otras normas de conflicto o aplicando ley

31 Este estudio analiza principalmente el ejercicio y aceptación de la autonomía de la voluntad en juicios ordinarios; se omiten los juicios arbitrales donde es comúnmente aceptada sujeta a los requisitos impuestos por las normas sobre arbitraje internacional.

32 Ver una lista de jurisprudencia en Eтcheberry (1960) p. 59.

33 Ver Davis, Turner \&Co. con Wolhmuth (1924); Ramos con Compañia de Azúcar de Chiclayo (1918).

34 Art. 14 Código Civil. Ver un análisis de esta norma en Claro (1898) Vol. I pp. 92-96; Fabres (1908) Vol. I pp. 17- 73. Ver también Ducci (2002) pp. 77-82; Ruz (2011) pp. 63-72

35 Ver Pacey con Barroso (1926). Ver también Hamilton (1966) p. 12; Guzmán (1997) p. 456; Ruz (2011) pp. 63-64.

36 Ver Ávila Mardones, Jorge (1989). Ver también, Claro (1898) Vol. I p. 97; Albonico (1950) Vol. II p. 15; Bezanilla (1966) pp. 57-59; Etcheberry (1960) pp. 10-11;Ruz (2011) pp. 67-72; Villarroel y Villarroel (1988) pp. 347-349. En contra: Guzmán quien argumenta que el art. 14 del Código Civil se refiere exclusivamente al estatuto personal del habitante de Chile, ver Guzmán (1997) p. 454.

37 Cuando, excepcionalmente, la ley chilena rige fuera del territorio, se aplica solo a los efectos que un acto produce en Chile y a la parte nacional que lo realiza: ver art. 15 Código Civil y Hamilton (1966) p. 12.

38 Ver Villarroel y Villarroel (1988) pp. 349, 353.

39 Ver arts. 14-16, 18 Código Civil y León (2002b) pp. 201-205. 
extranjera, sin que el derecho Internacional Privado chileno les proporcione criterios claros para realizar esta tarea ${ }^{40}$. Así, cuando la ley sustantiva chilena es inaplicable a un hecho, las normas de conflicto chilenas son incapaces de otorgar seguridad jurídica a las partes acerca de qué ley lo rige ${ }^{41}$.

Este territorialismo, que se justificó por razones históricas ${ }^{42}$, parece hoy anacrónico y por ello se ha propuesto su abandono y reemplazo por un nuevo sistema de derecho internacional privado que acepte y regule la aplicación del derecho extranjero en Chile incluyendo normas protectoras de los intereses fundamentales chilenos ${ }^{43}$. Desgraciadamente, hasta ahora, no se ha elaborado oficialmente un proyecto de ley al efecto.

Las normas chilenas relativas a contratos están inspiradas también por el principio de libertad contractual, consagrado en el Código Civil para contratos civiles, pero aplicable supletoriamente también a los contratos comerciales ${ }^{44}$. Así, la libre voluntad de las partes es el elemento fundante en la creación de un contrato y en la determinación de sus efectos quedando sujeta a mínimas limitaciones ${ }^{45}$. La importancia de esta voluntad se refleja en diversas normas ${ }^{46}$ y en el hecho de que puede interponerse recurso de casación en el fondo contra la sentencia dictada con infracción de una cláusula contractual ${ }^{47}$. En definitiva, la ley chilena otorga a las partes una amplia libertad para celebrar contratos nacionales; sin embargo, esta libertad se ve restringida en los contratos internacionales por el fuerte territorialismo de esta ley.

\section{B. La autonomía de la voluntad en la legislación chilena}

Las normas reguladoras de la ley aplicable a los contratos internacionales de mayor aplicación son el art 113 del Código de Comercio para contratos comerciales ${ }^{48}$, el art 16 del Código Civil para contratos civiles y el Decreto Ley 2.349 para contratos celebrados por el Estado y empresas públicas ${ }^{49}$. Las normas del Código de Bustamante y de la Convención de Viena Relativa al Contrato Internacional de Compraventa de Mercaderías de

\footnotetext{
40 LEÓN (2002b) p. 204.

41 Por ejemplo, para determinar el estado civil de un extranjero, los tribunales chilenos han aplicado en algunos casos una ley extranjera y en otros la ley chilena. Ver Martínez con Martínez de Acevedo (1908) y Jaluff(1943).

42 Ver Fabres (1908) pp. 114-123; León (2002b) pp. 202-203; Samtleben (1983). p 5.

43 León (2002a) p. 184.

44 Art. 1545 Código Civil; art. 96 Código de Comercio.

45 Ver art. 1445 Código Civil; Hauschild y otra con Urrutia (1957). Ver también, Ducci (2002) pp. 24-28; León (1963) pp. 76-79; Lira (1957) pp. 210-211 y 240; López (2010) pp. 191-198; Ruz (2011a) pp. 26-29, (2011b) pp. 11-16.

46 Arts. 1545, 1560, 1567, 1802, 1921 Código Civil. Ver también Zolezzi y otra con Gallardo (1955); MEZA (1966) Vol. I p. 31.

47 Ver Déliz con Compañia de Seguros Liverpool y otros (1910); Sociedad Hauts Fourneaux, Forges et Aciéries du Chili con Conde Armanol y otro (1926); Sorucco, Echeverría y Cía. Ltda. con Sorucco, Echeverría Ltda. (1943).

48 Según la opinión de los abogados entrevistados -ver infra $\mathrm{N}^{\circ} 75-$ los contratos comerciales son los más comunes en Chile.

49 Decreto Ley 2.349, de 1978.
} 
$1980^{50}$ son de escasa aplicación, las primeras por su carácter supletorio ${ }^{51}$ y las segundas porque las partes pueden dejarlas sin efecto en los contratos de compraventa internacional de mercaderías ${ }^{52}$. Por eso, serán excluidas de este análisis junto con las normas de la Convención de Varsovia sobre Ciertas Reglas Relativas al Transporte Aéreo Internacional de $1929^{53}$, que a pesar de ser de amplia aplicación en contratos de transporte aéreo de pasajeros, prohíben la autonomía ${ }^{54}$.

El art. 113 del Código de Comercio establece que los actos concernientes a la ejecución de contratos celebrados en el extranjero para cumplirse en Chile se rigen por la ley chilena a menos que las partes acuerden otra cosa. De este modo, autoriza a las partes para elegir una ley extranjera para regir los efectos de esos contratos en Chile. La doctrina interpreta este artículo más ampliamente y considera que autoriza esta elección para cualquier contrato comercial internacional -celebrado en Chile o en el extranjero- y para cualquier efecto, ya sea producido en Chile o no ${ }^{55}$. Esta interpretación ha sido acogida por los abogados nacionales ${ }^{56}$ pero no siempre por los jueces, quienes han rechazado cláusulas de elección de ley extranjera en contratos cumplideros en Chile argumentando la necesidad de aplicar las normas imperativas chilenas o de proteger el orden público nacional ${ }^{57}$. Así, la

${ }^{50}$ Decreto 544, de 1990.

51 El Código de Bustamante fue suscrito con dos reservas: una hecha por la Delegación chilena al momento de la firma y la segunda por el Congreso como condición para su aprobación. La primera dice: "pero (Chile) salvará su voto en las materias y en los puntos que estime convenientes, en especial, en los puntos referente a su política tradicional o a su legislación nacional", y la segunda reserva específica que "con relación a los conflictos que se produzcan entre la Legislación Chilena y alguna extranjera, los preceptos de la legislación actual o futura de Chile prevalecerán sobre dicho Código, en caso de desacuerdo entre unos y otros".

52 Los abogados chilenos tienden a excluir la aplicación de la Convención de Viena de 1980 en los contratos, en conformidad con el art. 6 de esa Convención: expresaron esto en la entrevista, ver infra $\mathrm{N}^{\circ} 75$.

53 Chile ha suscrito esta Convención con sus Protocolos de La Haya de 1955 (Decreto 458, de 1979) y de Montreal de 1975 (Decreto 1383, de 1997).

54 Art. 32 Convención de Varsovia, 1929.

55 Albónico (1943) p. 143; Villarroel y Villarroel (1990) p. 364. En contra Guzmán (1969) p. 216 quien interpreta el art. 113 como rechazando la autonomía pero autorizando a las partes a desplazar ciertas normas supletorias que, en ausencia de elección, se aplicarían al contrato. En GuZMÁN (1997) pp. 518-522 él, sin embargo, considera que el art. 113 permite que una cláusula de elección de ley extranjera sea un elemento que la Corte tenga en cuenta para localizar el contrato y determinar la ley que lo rige.

56 Los abogados chilenos habitualmente incluyen cláusulas de elección de ley extranjera en contratos comerciales internacionales celebrados en Chile y consideran que estas cláusulas no necesitan pactarse en el extranjero para ser válidas en el país. Del mismo modo, consideran que en Chile estas cláusulas son válidas cualquiera sea el lugar de cumplimiento del contrato, sin embargo, cuando el contrato se refiere a bienes situados en Chile como, por ejemplo, a una hipoteca o prenda sobre dichos bienes, acostumbran elegir, alternativamente, la ley chilena para gobernarlo de modo de asegurar su ejecución forzada en el país (art. 16 Código Civil). Esta fue la opinión mayoritaria de los abogados entrevistados: ver infra $\mathrm{N}^{\circ} 75$.

57 Aceptando la autonomía ver Corte de Apelaciones de Santiago, 31-VII-2003 no 11.276-2002 (no publicada) donde la Corte aceptó la elección de la ley del Estado de Delaware pero rechazó la acción interpuesta por el demandante por no haber este probado el contenido de esa ley. Rechazando la autonomía ver $H$.J. Broom y Cía con Exportadora Frutícola Antumalal (1999) donde la Corte Suprema denegó eficacia a la cláusula de elección de ley española acordada por las partes y aplicó las normas sobre contratos de transporte marítimo del Código de Comercio por estimarlas normas imperativas para las partes; Aerochile Ltda. con Insignia Limited (1997), no publicada, donde la Corte Suprema aplicó las normas del Código de Aeronáutica por sobre la ley inglesa elegida por las partes. 
autorización legal de la autonomía para los contratos comerciales internacionales ha sido limitada por la tendencia judicial a aplicar a estos contratos la ley chilena por sobre aquella elegida por las partes.

No existe norma legal autorizando la autonomía para los contratos civiles internacionales. La doctrina considera que las cláusulas de elección de ley extranjera en estos contratos son válidas conforme al art 1545 del Código Civil que otorga amplia libertad contractual a las partes $^{58} \mathrm{y}$, específicamente, conforme al art 16 del Código Civil que reconoce la validez de los contratos celebrados en el extranjero ${ }^{59}$. La aceptación de estas cláusulas en el art. 16 resulta, sin embargo, dudosa ya que su inciso final establece que "los efectos de los contratos otorgados en país extraño para cumplirse en Chile, se arreglarán a las leyes chilenas” pareciendo rechazar cualquier otra ley elegida por las partes. Alguna doctrina considera que este inciso es aplicable solo en ausencia de elección de ley por las partes ${ }^{60}$, otra que ordena que solamente la ejecución del contrato en Chile debe conformarse a la ley chilena ${ }^{61}$, mientras que otra entiende que es una norma imperativa que somete a la ley chilena todos los efectos que un contrato extranjero pueda producir en Chile desestimando cualquier otra ley que les pueda ser aplicable ${ }^{62}$. Del mismo modo, la interpretación judicial de este art 16 ha sido inconsistente: algunos jueces la han interpretado como aceptando la autonomía en contratos para cumplirse en Chile ${ }^{63}$ y otros como ordenando imperativamente la aplicación de la ley chilena a estos contratos ${ }^{64}$. Es decir, la ley y la jurisprudencia no dan certeza respecto a la aceptación de la autonomía en contratos civiles internacionales y evidencian el conflicto no resuelto entre territorialismo y libertad contractual en la legislación chilena ${ }^{65}$.

El Decreto ley 2.349 acepta la elección de ley y foro extranjeros en contratos económicos o financieros celebrados por el Estado chileno o las empresas públicas con empresas internacionales con asiento principal de sus negocios en el extranjero ${ }^{66}$; o en aquellos cele-

\footnotetext{
58 Ver Domínguez (1966) p. 296; Veloso (1931) p. 10; Villarroel y Villarroel (1990) pp. 358-359.

59 Art. 16 Código Civil. Interpretando este artículo como autorizando la autonomía para contratos civiles ver Albónico (1943) p. 143; GuZmán (1997) p. 522; Maluenda (1998) pp. 53-54.

60 Ramírez (2010) p 136; Villarroel y Villarroel (1990) p. 364.

61 Etcheberry (1960) p. 59.

62 Ver Claro (1898) Vol. I p. 119 quien opina que la aplicación imperativa de la ley chilena se limita a los contratos relativos a bienes situados en Chile; y FABres (1908) pp. 178-181 quien, influenciado por Savigny, afirma que la aplicación imperativa de la ley chilena obedece a una elección presunta de la ley chilena realizada por las partes al contratar con la intención de cumplir el contrato en Chile.

${ }^{63}$ Ver Davis, Turner \&Co. con Wolhmuth (1924); Ramos con Compañia de Azúcar de Chiclayo (1918); Tobar y otros con Fisco (1921). En State Street Bank and Trust Company con Inversiones Errázuriz Ltda. y Otros (2007) la Corte Suprema acepta la cláusula de elección de ley del Estado de Nueva York argumentando que "los bienes del demandado ubicados en Chile no han quedado directamente vinculados a la legislación extranjera, por lo que no se contraría la regla del inciso primero del artículo 16 del Código Civil”.
}

${ }^{64}$ Hoffman con Fisco (1911); Napias con Dumas (1878); Prunet con Sociedad Anónima La Industrial (1874). Estas sentencias interpretan el párrafo final del artículo 16 del Código Civil como una norma de orden público, ver Etcheberry (1960) p. 59. En State Street Bank and Trust Company con Inversiones Errázuriz Ltda. y Otros (2007) la Corte Suprema reitera esta doctrina al considerar que una elección de ley extranjera para gobernar un contrato es ineficaz cuando vincula directamente bienes ubicados en Chile a esa ley.

65 Etcheberry (1960) pp. 58- 59.

${ }^{66}$ Decreto Ley 2.349, de 1978 se aplica también a contratos celebrados por empresas cuyo 50 o más por ciento de su capital pertenezca al Estado de Chile o a una empresa pública (art. 3). 
brados por terceros con la garantía del Estado o una empresa pública chilena ${ }^{67}$. Esta elección debe ser autorizada por el Presidente de la República para ser válida ${ }^{68}$.

Una parte de la doctrina considera la dictación de este decreto como una importante confirmación de la aceptación de la autonomía en la legislación chilena, a pesar de su restrictivo campo de aplicación ${ }^{69}$. Argumenta que si la autonomía es aceptada para los contratos públicos, es lógico también aceptarla para los contratos privados. Además, recalca que los Considerandos de este Decreto Ley confirman la aceptación de la autonomía para los contratos privados en el sistema jurídico chileno. En efecto, estos Considerandos, a la par que enfatizan la conveniencia de aceptar la autonomía para contratos públicos, exponen que las cláusulas de elección de ley y foro extranjeros en contratos privados internacionales son comunes en la práctica comercial internacional, y válidas en la legislación chilena y el Código de Bustamante ${ }^{70}$. Parece, sin embargo, que la importancia de esta referencia debiera ser juzgada tomando en consideración que fue formulada por el legislador para fundamentar la autorización de la elección de ley o foro extranjeros en los contratos públicos, pero no como una interpretación auténtica de la ley chilena en relación a la validez de esta elección en otros contratos. En consecuencia, aunque evidencia una tendencia a la aceptación legislativa de la autonomía, no clarifica vinculantemente la legislación relativa a la autonomía en contratos privados, ni puede ser considerada como una aceptación legal de la autonomía para estos contratos.

Los autores nacionales han sostenido normalmente que la ley chilena acepta la autonomía de la voluntad a pesar de la ausencia de claras normas legales al respecto ${ }^{71}$. Los abogados nacionales comparten unánimemente esta opinión y utilizan la autonomía con frecuencia en los contratos internacionales. Sin embargo, normalmente se precaven frente a un posible rechazo de la elección de ley extranjera, sometiendo los contratos que se refieren a bienes situados en Chile a la ley chilena para asegurar su ejecución judicial en el país ${ }^{72}$. Esta sumisión es necesaria porque la ejecución judicial de sentencias ordinarias o arbitrales extranjeras relativas a estos bienes es incierta ya que tiende a ser denegada por la Corte Suprema a pretexto de proteger el orden público o la jurisdicción chilena ${ }^{73}$.

\footnotetext{
${ }^{67}$ Art. 1 Decreto Ley 2.349, de 1978.

${ }_{68}$ Art. 4 Decreto Ley 2.349, de 1978.

69 Ramírez (2010) p. 135; Villarroel y Villarroel (1990) p. 359.

70 Decreto Ley 2.349, de 1978 Considerandos no 1-3.

${ }^{71}$ Ha habido opiniones contrarias: Claro y Fabres, comentaristas tempranos del Código Civil, no se refirieron a la autonomía y parecen interpretar el artículo 16 del Código Civil como una norma imperativa que ordena la aplicación de la ley chilena a los contratos internacionales celebrados o cumplidos en Chile; Domínguez y Guzmán, siguiendo la teoría de la localización de Batiffol, afirman que las elecciones de ley son indicadores que los tribunales deben tener en cuenta para localizar un contrato de modo de determinar la ley que lo gobierna; y Etcheberry que afirma que la ley chilena no acepta claramente la autonomía de la voluntad en contratos civiles. Ver Claro (1898) Vol. I pp. 92-121; Fabres (1887) pp. 133-143 y (1908), Vol. I pp. 13-193; Domínguez (1966) pp. 282-283, 295-299; GUZMÁn (1997) pp. 519-521; ETCHeBerRy (1960) pp. 58-59.

72 Expresaron esta opinión en la entrevista, ver infra $\mathrm{N}^{\circ} 75$.

73 Ver Fiscal con Moreno M., Jaime (1999) donde la Corte rechazó la ejecución de una sentencia argentina argumentando que el artículo 16 del Código Civil establece que los bienes situados en Chile están regidos por la ley y jurisdicción chilena. Ver una lista de casos similares en Repertorio de Legislación y Jurisprudencia Chilenos. Código Civil y Leyes Complementarias (1996) pp. 115-116.
} 
La aceptación de la autonomía de la voluntad ha sido discutida en los tribunales chilenos en pocas ocasiones. Los abogados nacionales señalan varias razones para explicarlo: primero, el alto nivel de cumplimiento de las obligaciones emanadas de contratos internacionales; segundo, la conveniencia de resolver las disputas que estos contratos originan extrajudicialmente o de renegociarlos en caso de incumplimiento de las obligaciones del contrato original; tercero, la preferencia para someter sus disputas a cortes arbitrales donde las cláusulas de elección de ley son normalmente acogidas; cuarto, la tendencia a someter estos contratos a la ley chilena cuando se refieren a bienes situados en Chile, en cuyo caso, los tribunales los consideran como equivalentes a contratos nacionales; y finalmente, la práctica de elegir una ley extranjera acompañada de la elección de un foro extranjero que lleva a que las disputas sean decididas por un tribunal extranjero ${ }^{74}$. Todas estas razones muestran que la escasez de jurisprudencia en relación a la autonomía no puede ser considerada como un indicador de la escasez de su utilización sino, al contrario, como una confirmación de la regularidad de su práctica.

En conclusión, la autonomía de la voluntad se utiliza habitualmente en Chile y necesita ser reglamentada en su legislación. La ley y la jurisprudencia chilenas son incapaces de otorgar certeza jurídica a las partes acerca de la validez de las cláusulas de elección de ley incluidas en contratos internacionales a cumplirse en Chile, a pesar del uso habitual de estas cláusulas. Parece conveniente modificar la ley chilena para reglamentar esta autonomía y perfeccionar el sistema chileno de derecho internacional privado que otorga excesivas prerrogativas al derecho nacional.

\subsection{LOS PROBLEMAS RELATIVOS AL EJERCICIO LA AUTONOMÍA DE LA VOLUNTAD EN LA LEGISLACIÓN CHILENA}

El ejercicio de la autonomía de la voluntad suscita una serie de problemas que, en su mayoría, no están regulados por la legislación chilena; por ello, su solución debe buscarse en la interpretación analógica de las normas chilenas sobre contratos y en la opinión de la jurisprudencia y doctrina nacional existente. Además, este artículo agrega en ciertos casos la opinión de los abogados nacionales para mostrar cómo se resuelven estos asuntos en la práctica $^{75}$. Cada uno de los problemas estudiados se introduce con una explicación de su solución en el derecho comparado a fin de aportar elementos para el análisis crítico de la solución que les brinda la legislación chilena.

\section{A. Problemas especificos relativos a la cláusula de elección de ley}

1. La posibilidad de una elección tácita de ley

Las legislaciones, en su mayor parte, aceptan la elección tácita de ley hecha por las partes $^{76}$; sin embargo, difieren en los requisitos o estándares exigidos para determinar su

\footnotetext{
74 Expresaron esta opinión en la entrevista, ver infra $\mathrm{N}^{\circ} 75$.

75 Para obtener suficiente información acerca del modo y de la extensión en que la autonomía es usada en Chile se solicitó a abogados destacados del área que contestaran un cuestionario al respecto. Se entrevistó a 27 abogados: 21 socios de estudios jurídicos y 6 asesores legales de bancos comerciales.

76 Ver, por ejemplo, art. 3 Convenio de Roma, de 1980; art. 3 Reglamento Roma I, del 2008; art 7 Convención de México, de 1994; art. 3540 Código Civil de Luisiana; Restatement, Second, Conflict of Laws $\$ 187$,
} 
existencia ${ }^{77}$. Algunas exigen una prueba contundente de modo que esa existencia sea indubitable y otras, una prueba convincente, que dé una certeza razonable acerca de ella ${ }^{78}$. Todas coinciden, sin embargo, en considerar que la elección es inexistente cuando las partes no la expresan al menos indirectamente en el contrato, o por medio de una conducta previa, concomitante o posterior relacionada con él ${ }^{79}$.

Las legislaciones no incluyen listas detalladas de indicadores o conductas específicas de las partes que puedan ser judicialmente consideradas para determinar la existencia de una elección implícita de ley. Existe, sin embargo, una tendencia a considerar que un hecho aislado, como la elección de un foro determinado o una referencia en el contrato que exprese que debe entenderse celebrado en un lugar específico, no son suficientes para deducir la elección de la ley de ese foro o de ese lugar de celebración ${ }^{80}$. Se exige, en general, que una elección tácita de ley se demuestre por medio de múltiples indicadores en el contrato y/o en la conducta de las partes. De este modo, estos indicadores deben permitir a los jueces deducir la existencia de una elección real de ley hecha por las partes y no de una presumida o hipotética ${ }^{81}$.

La ley chilena parece aceptar estas elecciones tácitas si se demuestran claramente. En efecto, ella no exige una elección de ley expresa en sus normas relativas a la autonomía ${ }^{82}$ y además otorga valor a la expresión tácita de la voluntad de las partes en un contrato. Así, establece que la voluntad de las partes, si es clara, prevalece por sobre las palabras literales del contrato ${ }^{83}$ y que la aceptación tácita de las partes a un contrato produce los mismos efectos que su aceptación expresa ${ }^{84}$; lo que permite deducir que las partes pueden elegir tácitamente la ley aplicable a un contrato.

La ley chilena no señala indicadores a tener en cuenta para determinar la existencia de una elección tácita de ley; tampoco existe jurisprudencia al respecto. Algunas normas sobre interpretación de los contratos del Código Civil pueden, si se aplican por analogía, aportar estos indicadores. Así, una elección tácita puede inferirse de una elección de ley expresa hecha en un contrato similar entre las mismas partes o cuando el comportamiento de las partes da a entender que consideran el contrato regido por cierta ley ${ }^{85}$. La existencia en un contrato de

comment a); Section 1-105 Uniform Commercial Code; art. 3111 Código Civil de Quebec; art. 1210 Código Civil de la Federación Rusa; art 116 Ley Federal Suiza de Derecho Internacional Privado; ver también Lando (1976) p. 46; Plender y Wilderspin (2009) pp. 141-142; Scoles et al. (2004) pp. 948-949.

77 Nygh (1999) pp. 109-110; Rabel (1947) pp. 384-387.

78 Por ejemplo, el art. 3 del Reglamento Roma I, del 2008 exige que la elección tácita sea demostrada claramente por los términos del contrato o las circunstancias del caso; en cambio, el art. 116 de la ley Federal Suiza de Derecho Internacional Privado exige solo que la elección se desprenda de manera cierta de las cláusulas contractuales o de sus circunstancias. Ver también Nygh (1999) pp. 109-110; Plender y Wilderspin (2009) pp. 142-154; RABEL (1947) pp. 385-386.

79 Informe Giuliano y Lagarde (1980) p. 17; Leible (2011) p. 222; Rabel (1947) pp. 384-387.

80 Nygh (1999) pp. 109-110; Rabel (1947) pp. 384-387.

81 Para una lista de posibles indicadores ver Informe Giuliano y Lagarde (1980) p. 17; Audit (2006) pp. 658-660; Nygh (1999) pp. 113-120.

82 Art. 113 Código de Comercio; art. 1 Decreto Ley 2.349, de 1978.

83 Art. 1560 Código Civil. Ver también Villarroel y Villarroel (1990) p. 360.

84 Art. 103 Código de Comercio.

85 Art. 1564 Código Civil. 
una cláusula que es eficaz o válida bajo una ley pero ineficaz o inválida bajo otra, puede indicar que las partes eligieron tácitamente la ley que le da valor ${ }^{86}$. Y, en general, cualquier evidencia clara de una elección de ley consignada en cualquier documento, declaración de testigos, costumbre, etc., incluyendo la petición de las partes de aplicar una cierta ley durante un procedimiento judicial, puede tomarse en cuenta para determinar la existencia de una elección implícita de ley. Esta elección implícita, sin embargo, debe deducirse de indicadores claros ya que la decisión más probable de los tribunales chilenos será aplicar la ley chilena a todos los contratos conectados con Chile debido al territorialismo de esta ley.

2. La validez de la cláusula de elección de ley

La mayoría de los sistemas legales considera que la validez formal y sustancial de la cláusula de elección de ley está gobernada por la ley elegida por las partes. Pero considera que, alternativamente, la validez formal de esta cláusula puede estar gobernada por otra ley, como la del lugar de celebración o de cumplimiento del contrato ${ }^{87}$, de modo que sea válida cuando cumple con las formalidades exigidas por cualquiera de estas leyes.

Aunque no hay norma específica al respecto, puede interpretarse que la legislación chilena somete la validez formal y sustancial de la cláusula de elección de ley a la ley del lugar de suscripción de esta cláusula ya que esta es la regla general para la validez de los contratos celebrados en Chile ${ }^{88}$, aplicable también -según la doctrina y jurisprudencia- a los contratos celebrados en el extranjero ${ }^{89}$. La posibilidad de someter esta validez a la ley elegida por las partes debe descartarse para los contratos internacionales civiles y comerciales porque las normas vigentes restringen el ámbito de aplicación de esta ley a los efectos de los contratos $^{90}$. Sin embargo, puede eventualmente aceptarse para los contratos gobernados por el Decreto Ley 2.349 ya que este decreto no contiene esta restricción ${ }^{91}$. Finalmente, debe descartarse también la posibilidad de someter la validez formal de esta cláusula alternativamente a otras leyes, por ser una solución ajena a la ley chilena ${ }^{92}$.

Esta solución chilena parece poco adecuada. En el caso de la validez formal de la cláusula, al excluir la referencia alternativa a otras leyes distintas de la del lugar de suscripción, impide que se dé valor a una cláusula que cumple con las formalidades de otras leyes más conectadas o relevantes para el contrato, como por ejemplo, la ley que rige sus efectos o la del lugar de su cumplimiento. Y, en el caso de la validez sustancial, separa la ley que gobierna esta validez de la ley que gobierna los principales aspectos del contrato. Por otra

\footnotetext{
86 Art. 1562 Código Civil.

87 Art. 9 Convenio de Roma, de 1980; art. 11 Reglamento Roma I, del 2008; arts. 12-13 Convención de México, de 1994, art.124 Ley Federal Suiza de Derecho Internacional Privado; art. 1181 Código Civil Argentino; art 2094 Código Civil Peruano; art. 37 Ley Venezolana de Derecho Internacional Privado.

${ }^{88}$ Arts. 14, 16 inc $2^{\circ}$, 1545 Código Civil y art. 22 Ley sobre el Efecto Retroactivo de las Leyes, de 1861. GuzMÁN (1997) pp. 514-515, 523-524. Ramírez sostiene, sin analizar detalladamente el tema, que la validez debiera estar determinada por la ley que autorizó el ejercicio de la autonomía, cfr. Ramírez (2010) p. 133.

89 Ver Duval i Diaz con Laureiro (1906); Domínguez (1966) pp. 296-299; Etcheberry (1960) pp. 57-58; Guzmán (1997) pp. 523-524; Ruz (2011) pp. 69-72.

90 Art. 16 Código Civil; art. 113 Código de Comercio.

91 Art. 1 Decreto Ley 2.349, de 1978.

92 Arts. 14, 17-18, 1027 Código Civil. Ver infra 2.2. B. 1.
} 
parte, someter la validez formal y sustancial de esta cláusula a la ley del lugar de celebración puede resultar inapropiado ya que muchas veces este lugar puede ser irrelevante o difícil de determinar, especialmente en contratos inter absentes; en cambio, someterla a la ley elegida por las partes resulta coherente y aumenta la certeza jurídica para las partes al disminuir el número de leyes que gobierna el contrato y permitirles optar por normas legales más adecuadas o conocidas por ellas.

\section{La existencia del consentimiento a la elección de ley}

Normalmente, en el derecho comparado, la existencia del consentimiento a la cláusula de elección de ley se rige por la ley elegida por las partes ${ }^{93}$. Sin embargo, algunas legislaciones permiten al juez tener en cuenta también la ley de la residencia habitual o del lugar del asiento de los negocios de una de las partes, de modo de determinar si esta prestó realmente su consentimiento a esa elección ${ }^{94}$; esto porque, en ocasiones, los efectos del silencio de una parte contratante pueden tratarse de modo distinto en estas leyes ${ }^{95}$.

La ley chilena parece regir la existencia de este consentimiento en contratos civiles y comerciales por la ley del lugar de suscripción de la cláusula, con la posible excepción en favor de la ley elegida por las partes para los contratos públicos regidos por el Decreto ley $2.349^{96}$. Es decir, la ley chilena es consistente en determinar que la existencia del consentimiento a esta cláusula está regida por la misma ley que rige su validez sustancial, sin embargo, esta solución no parece del todo adecuada; la posibilidad de referencia alternativa a la ley de la residencia habitual o a la ley elegida por las partes para determinar la existencia de este consentimiento puede otorgar una solución más justa, esto porque la ley del lugar de suscripción puede acoger una cláusula que nunca fue aceptada por una de las partes, por ejemplo, cuando esta ley considera al silencio de una parte como un consentimiento implícito a la cláusula y la ley de la residencia habitual o aquella elegida por las partes no lo hace.

\section{Independencia de la cláusula de elección de ley del contrato}

En derecho comparado se discute si la cláusula de elección de ley tiene una existencia independiente o forma parte integral del contrato; esta discusión cobra relevancia cuando la existencia o nulidad de un contrato está en disputa. En efecto, si la cláusula se considera independiente del contrato, la disputa se resuelve por la ley elegida por las partes la que desplaza cualquier otra ley aplicable al mismo. Si la cláusula, en cambio, se considera como parte del contrato, la disputa se resuelve por la ley putativa del contrato determinada por las normas de conflicto del foro ${ }^{97}$.

93 Art. 8 Convenio de Roma, de 1980; art. 10 Reglamento Roma I, del 2008; art. 12 Convención de México, de 1994; Restatement, Second, Conflict of Laws $\$ 187$, comment b), $\$ 198$ comment a), $\$ 199$ comment a), $\$$ 200 comment a); art.116 Ley Federal Suiza de Derecho Internacional Privado; ver también NyGH (1999) p. 85; Plender y Wilderspin (2009) pp. 420-428; Scoles et al. (2004) p. 955.

94 Art. 8 Convenio de Roma, de 1980; art. 10 Reglamento Roma I, del 2008; art. 12 Convención de México, de 1994.

95 Informe Giuliano y Lagarde (1980) p. 28.

96 Ver supra 2.2. A. 2.

97 Ver art. 8 Convenio de Roma, de 1980; art. 10 Reglamento Roma I, del 2008; art. 12 Convención de Méxi- 
Actualmente, existe un creciente consenso en las legislaciones mundiales respecto a considerar que la cláusula de elección de ley incluida en un contrato tiene un carácter independiente del mismo ${ }^{98}$. Esta independencia es obvia, cuando ella consta en un acuerdo ad hoc.

En Chile no hay norma ni jurisprudencia en relación a este asunto, sin embargo, puede interpretarse que la legislación considera esta cláusula como una parte del contrato, sometida a la ley que lo gobierna real o putativamente. Esto porque la ley elegida no hace nacer al contrato sino que solo gobierna sus efectos. De este modo, en Chile, la elección de ley se considerará ineficaz cuando se discuta la existencia o nulidad del contrato y la disputa será resuelta conforme a las normas chilenas de conflicto ${ }^{99}$. Esta solución parece menos respetuosa de la voluntad de las partes y más inconsistente con el principio de la autonomía de la voluntad que aquella aportada por el derecho comparado.

5. Momento de la elección de ley y cambios subsecuentes de la misma

El derecho comparado considera que un corolario básico de la aceptación de la autonomía de la voluntad es facultar a las partes para elegir ley aplicable en cualquier momento y cambiar esta elección si lo estiman conveniente, todo ello sujeto a algunos límites para proteger los derechos de terceros que pudieren verse afectados negativamente por estos cambios $^{100}$. Esta protección está normalmente regida por la ley del foro, aunque alguna doctrina sugiere que debiera estar regida por la ley que rige la obligación con el tercero ${ }^{101}$.

Parece lógico que los cambios de elección de ley y sus límites estén regidos por las normas de conflicto del foro, así la misma ley que autorizó a las partes a elegir una ley es quien las autoriza a cambiarla ${ }^{102}$. Sin embargo, cuando estos cambios se realizan dentro de un procedimiento judicial, su eficacia queda entregada a las normas procesales del foro ${ }^{103}$.

Los efectos de estos cambios debieran, en general, quedar sometidos a la nueva ley elegida pues esta solución parece acorde con la naturaleza independiente de la cláusula de elección de ley ${ }^{104}$. Así, esta nueva ley será la que determine si el cambio tiene efecto retroactivo o si solo rige para el futuro, o si las partes pueden acordar darle a este cambio uno de estos dos efectos. Algunos sistemas legales consagran, sin embargo, una excepción respecto

\footnotetext{
co, de 1994; art. 10 (2) Ley Rumana de Derecho Internacional Privado, de 1992, que atribuyen eficacia a la ley elegida para determinar la existencia o validez del contrato. Ver también Nygh (1999) pp. 84-85: Plender y Wilderspin (2009) pp. 420- 429.

98 Ver art. 8 Convenio de Roma, de 1980; art. 10 Reglamento Roma I, del 2008; art. 12 Convención de México, de 1994. Ver también Nygh (1999) p. 85; Ramírez (2010) p. 133.

99 Art. 16 Código Civil; art. 113 Código de Comercio.

100 Informe Giuliano y Lagarde (1980) p. 18; Lando (1985) pp. 314-318; Leible (2011) p. 223; Plender y Wilderspin (2001) p. 101 y (2009) pp. 154-158. Esta protección está establecida, por ejemplo, en art. 3 (2) Convenio de Roma, de 1980, art. 3 (2) Reglamento Roma I, del 2008, art. 8 Convención de México, de 1994 y art 116 Ley Federal Suiza de Derecho Internacional Privado.

101 Nygh (1999) pp. 102-103.

102 Esta parece ser la solución propuesta por el art. 3 de la Convención de Roma, de 1980, ver Informe GiULiano y Lagarde (1980) p. 18. En contra Nygh considera que el derecho de cambiar la ley debe regirse por las normas de la nueva ley elegida: Nygh (1999) p. 101 ver también Plender y Wilderspin (2009) p. 157.

103 Informe Giuliano y Lagarde (1980) p. 18.

104 Leible (2011) p. 223; Nygh (1999) p. 102; Plender y Wilderspin (2001) pp. 102-103 y (2009) pp. 155-156.
} 
a la validez formal de los contratos ${ }^{105}$; en ellos, el cambio de ley aplicable no afecta la validez formal del contrato establecida conforme a la ley antigua ${ }^{106}$.

La ley chilena carece de restricciones o prohibiciones acerca del momento de la elección de ley y, por ello, puede interpretarse como autorizando que esta elección y sus cambios se hagan antes, durante o después de la celebración del contrato ${ }^{107}$, conclusión que es respaldada por la práctica contractual chilena ${ }^{108}$. Los cambios en la elección, en principio, podrían hacerse expresa o tácitamente pero, en este último caso, debieran demostrarse por múltiples e inequívocos indicadores ${ }^{109}$. Su efecto retroactivo o hacia el futuro debiera estar gobernado por la nueva ley elegida por las partes, que es la que rige los efectos del contrato ${ }^{110}$.

En Chile, el cambio en la ley aplicable no afecta la validez formal del contrato porque esta está fuera del ámbito de esa ley ${ }^{111}$. Este cambio tampoco debe afectar negativamente los derechos de terceros, ya que estos derechos pueden considerarse protegidos en la legislación chilena si se aplica, por analogía, la norma que prohíbe a las partes renunciar a derechos si esa renuncia afecta los intereses de terceros y aquella que permite a terceros interesados solicitar la nulidad absoluta de ciertos actos afectados por ciertos vicios ${ }^{112}$.

6. Multiplicidad de elecciones de ley o división de la ley del contrato

La posibilidad de que las partes elijan múltiples leyes para gobernar distintas partes de un contrato o de que ellas dividan la ley que lo gobierna es otra consecuencia de la autonomía aceptada por múltiples sistemas legales ${ }^{113}$. También lo es la posibilidad de hacer elecciones parciales de ley, es decir, de elegir una ley para gobernar una parte del contrato dejando el resto regido por la ley determinada por las normas de conflicto del foro.

Esta multiplicidad o división debe distinguirse del hecho de que ciertos aspectos del contrato, como la capacidad de las partes o su validez formal quedan, en muchos sistemas legales, regidos por otras leyes distintas de la ley que gobierna al contrato ${ }^{114}$. Debe

105 Art. 3 (2) Convenio de Roma, de 1980; art. 3 (2) Reglamento Roma I, del 2008; art. 8 Convención de México, de 1994.

106 Este es el caso de los países de la Unión Europea y de México y Venezuela donde la Convención de México está en vigor: art. 3 (2) Convenio de Roma, de 1980; art. 3 (2) Reglamento Roma I, del 2008; art. 8 Convención de México, de 1994. Ver también Leible (2011) p. 223; Nygh (1999) p. 127; Plender y Wilderspin (2009) pp. 158-159, 425-427.

107 Arts. 16, 1545 Código Civil; art. 113 Código de Comercio; art. 1 Decreto Ley 2.349, de 1978.

108 Art. 16 Código Civil; art. 113 Código de Comercio; art. 1 Decreto Ley 2.349, de 1978. Del mismo modo los abogados entrevistados (supra $\mathrm{n}^{\circ} 75$ ) consideran que la elección de ley puede hacerse antes, durante o después de la celebración del contrato, incluso durante la tramitación del juicio.

109 Ver supra 2.2. A. 1.

110 Ver infra 2.2. B. 4.

111 Ver infra 2.2. B. 1.

112 Arts. 12, 1683 Código Civil.

113 Art. 3 (1) Convenio de Roma, de 1980; art. 3 (1) Reglamento Roma I, del 2008; art. 7 Convención de México, de 1994; Art 14 V Código Civil Federal Mexicano; art 7 Ley Venezolana de Derecho Internacional Privado; art. 3111.1 Código Civil de Quebec; art. 75 Ley Rumana de Derecho Internacional Privado, de 1992. Ver también Informe Giuliano y Lagarde (1980) p. 17; Nygh (1999) pp. 128-138; Plender y Wilderspin (2001) p. 388 y (2009) pp. 154-155.

114 Art. 1 (2) Convenio de Roma, de 1980; art. 1 (2) Reglamento Roma I, del 2008; art. 5 Convención de México, de 1994; art. 35 Ley Federal Suiza de Derecho Internacional Privado; ver infra 2.2. B. 1 y 3. 
distinguirse también de la incorporación de cierta ley en un contrato que, como se ha visto anteriormente, no modifica la ley que lo gobierna. Cuando las partes dividen el contrato ellas eligen dos o más leyes para regir partes separadas del contrato las que, sin mediar la división, quedarían regidas por una misma ley ${ }^{115}$.

Parece que la ley que debe autorizar la división de ley debe ser la misma que autoriza la elección de ley, es decir la ley del foro ${ }^{116}$. Esta misma ley debe determinar las condiciones y requisitos para proceder a esta división. Al respecto, existe consenso en que la posibilidad de división debe limitarse en ciertos casos, por ejemplo, cuando esta división se realiza para evadir normas imperativas o de policía del foro o de la ley que gobierna el contrato ${ }^{117}$. También hay acuerdo en que debe exigirse que la división sea lógicamente consistente; es decir, que se refiera a aspectos del contrato que puedan ser separados y gobernados, coherentemente, por diversas leyes ${ }^{118}$.

La ley chilena parece aceptar la división de ley para todo tipo de contratos puesto que sus normas no la prohíben ${ }^{119}$. Esta conclusión es además confirmada por la práctica legal, que realiza esta división, aunque excepcionalmente ${ }^{120}$. Esta división puede hacerse en forma expresa o tácita ${ }^{121}$ y puede someter un aspecto particular del contrato a una ley dejando el resto para ser gobernado por la ley principal del contrato, o bien, someter diversos aspectos del contrato a diversas leyes ${ }^{122}$.

Corresponde a las partes determinar el ámbito en el que las diversas leyes deben ser aplicadas y reconciliadas. Parece, sin embargo, que los jueces chilenos pueden rechazar una elección de ley que no pueda ser lógicamente reconciliada con las demás leyes que gobiernan el contrato ${ }^{123}$. Ellos podrían también rechazar la división hecha con el propósito de

\footnotetext{
115 El contrato se divide cuando las partes eligen distintas leyes para gobernar distintos aspectos del contrato como, interpretación, cumplimiento y consecuencias de incumplimiento, extinción de las obligaciones y nulidad que normalmente están gobernadas por la ley principal del contrato: ver art. 10 Convenio de Roma, de 1980; art. 12 Reglamento Roma I, del 2008; art. 14 Convención de México, de 1994. Ver Plender y WilDERSPIN (2009) pp. 154-155.

116 Nygh (1999) p. 137.

117 Art. 3 (3) Convenio de Roma, de 1980; art 3 (3) Reglamento Roma I, del 2008, art. 11 Convención de México, de 1994; ver también Informe Giuliano y Lagarde (1980) p. 17.

118 Esta es la solución prevista por el art. 3 del Convenio de Roma, de 1980: ver Informe GiUliano y LAGARDE (1980) p. 17 aplicable también al art 3 del Reglamento Roma I, del 2008; ver también art. 14 V Código Civil Federal Mexicano; art. 7 Ley Venezolana de Derecho Internacional Privado; art. 9 Convención Interamericana de Normas Generales de Derecho Internacional Privado, Montevideo 1979; Leible (2011) p 224; Nygh (1999) p. 132; Kassis (1993) pp. 356-359; Loussouarn et al. (2004) pp. 498-499.

119 Art. 16 Código Civil; art. 113 Código de Comercio; art. 1 Decreto Ley 2.349, de 1978.

120 Boggiano (1983) p. 437. En Chile, la división del contrato se hace excepcionalmente, por ejemplo, en ocasiones se elige una ley distinta para gobernar aspectos técnicos del contrato que requieren de una regulación especial o que son accesorios al contrato mismo como puede ser la evaluación de los daños.

121 Ver supra 2.2. A. 1.

122 Art. 16 Código Civil; art. 113 Código de Comercio; art. 1 Decreto Ley 2.349, de 1978.

123 Art. 9 Convención Interamericana de Normas Generales de Derecho Internacional Privado, Montevideo 1979 suscrita pero no ratificada por Chile. Esta es también la solución del art. 3 Convenio de Roma, de 1980, aplicable al art. 3 del Reglamento Roma I, del 2008, ver Informe Giuliano y Lagarde (1980) p. 17.
} 
evadir normas imperativas o de orden público chilenas o de otro sistema legal conectado con el contrato ${ }^{124}$.

\section{Autonomía material o sustantiva}

Alguna doctrina ha sostenido que si las partes pueden excluir totalmente una ley que, en ausencia de elección, habría sido la ley que rige el contrato pueden igualmente excluirla parcialmente o bien elegir una ley excluyendo alguna de sus normas. Así, de acuerdo a esta doctrina, las partes tienen el derecho a elegir una ley y excluir sus normas imperativas ${ }^{125}$ incorporando al contrato normas sustantivas contrarias o derogatorias de esas normas imperativas $^{126}$. Este tipo de autonomía se ha llamado autonomía sustantiva o material para diferenciarla de la autonomía conflictual, que es la autonomía sobre la que versa este estudio ${ }^{127}$.

La posibilidad de practicar la autonomía sustantiva tiene siempre límites ${ }^{128}$ : las partes no pueden excluir las normas imperativas sobre contratos internacionales del foro ni aquellas que protejan su orden público y, en algunos sistemas legales, tampoco las normas imperativas de otra ley con una conexión sustancial con el contrato ${ }^{129}$.

La autonomía sustantiva parece ser aceptada por la legislación chilena a pesar de la falta de jurisprudencia y de doctrina al respecto. Los abogados nacionales incorporan frecuentemente cláusulas contractuales que dejan sin efecto normas imperativas de la ley que gobierna al contrato como, por ejemplo, los International Commercial Terms (Incoterms) en contratos de compraventa de mercaderías o las Uniform Custom and Practice for Documentary Credits (UCP) en créditos documentarios, y estas cláusulas pueden considerarse aceptadas dentro del marco general de libertad contractual otorgado a las partes por la legislación chilena ${ }^{130}$. Además, la Convención de Viena, 1980, autoriza esta autonomía al permitir a las partes excluir total o parcialmente la aplicación de la Convención a un contrato, o modificar sus normas, o someter el contrato a cualquier costumbre o uso acordado por las partes $^{131}$.

En todo caso, la autonomía sustantiva tiene límites: las partes no pueden dejar sin efecto normas de policía del foro o protectoras del orden público chileno en relación a contratos internacionales ${ }^{132}$. No existe, sin embargo, impedimento para excluir normas imperativas de terceros Estados conectados con el contrato ${ }^{133}$.

\footnotetext{
124 Ver infra 2.2 C. 4 y 5.

125 Ver infra 2.2. C. 5. respecto a las normas imperativas.

126 Boggiano (1983) p. 438 y (2000) pp. 682 y ss.; Nygh (1999) pp. 136-137.

127 Ver un estudio sobre la autonomía sustantiva en Boggiano (1991) Capítulo III pp. 25-57. Ver también Leible (2011) pp. 37-40; Nygh (1999) pp. 175-176.

128 Boggiano (1983) p. 439; Nygh (1999) p. 137.

129 Art. 3 (3), 7 Convenio de Roma, de 1980; arts. 3 (3), 3 (4), 9 Reglamento Roma I, del 2008, art 11 Convención de México, de 1994 .

130 Arts. 16, 1545 Código Civil; art. 113 Código de Comercio; art. 1 Decreto Ley 2.349, de 1978.

131 Arts. 6, 9 Convención de Viena, 1980. Ver también Kaller (1995) pp. 352-354.

132 Arts. 1461, 1467 Código Civil; Ver también Boggiano (1983) p. 439; Nygh (1999) p. 176; Villarroel y Villarroel (1990). p. 359.

133 En contra: Villarroel y Villarroel (1990) p. 359 quienes afirman que las partes no pueden desplazar fraudulentamente las normas imperativas de un tercer Estado cuando su ley es la más conectada al contrato por
} 


\section{B. El ámbito de aplicación de la ley elegida}

El derecho comparado está de acuerdo en considerar que la ley elegida debe regir los aspectos principales del contrato, es decir, su existencia, validez sustancial, efectos, interpretación, los modos de cumplimiento de las obligaciones que genera, las consecuencias de su incumplimiento, la evaluación de los daños y los efectos de la nulidad del contrato mismo ${ }^{134}$. También está de acuerdo en considerar que la validez formal del contrato debe estar regida por la ley elegida ${ }^{135}$, teniendo en cuenta también otras leyes, como la de la residencia habitual de una de las partes, o la del lugar de celebración o cumplimiento del contrato ${ }^{136}$.

La ley chilena, sin embargo, se aparta de esta tendencia al restringir el ámbito de aplicación de la ley elegida solo a los efectos del contrato. Más adelante, se mostrará cómo esta restricción aumenta la incertidumbre jurídica para las partes y refleja una limitada aceptación de la autonomía de la voluntad en esta ley.

\section{Validez formal de los contratos}

El derecho comparado sometió tradicionalmente las formalidades de un contrato a la ley del lugar de su celebración ${ }^{137}$. Sin embargo, esta regla ha sido reemplazada por otra que permite la referencia alternativa a las diversas leyes conectadas con el contrato para determinar su validez formal teniendo en cuenta la conveniencia de evitar la invalidez de un contrato por defectos puramente formales ${ }^{138}$. Así en importantes sistemas legales las formalidades están hoy regidas por cualquiera ley conectada al contrato, por ejemplo, la elegida por las partes, la del lugar de celebración del contrato, la del lugar donde una de las partes esté al momento de contratar, la del lugar donde el consumidor tiene su residencia habitual, la del lugar de ejecución del contrato, etc. ${ }^{139}$.

En Chile, no se sigue esta solución; la jurisprudencia y doctrina consideran que la validez formal del contrato se rige exclusivamente por la ley del lugar de su celebración ya que esta es la norma imperativa establecida para la validez de los contratos celebrados en Chile y para la de ciertos actos celebrados en el extranjero ${ }^{140}$. La referencia alternativa a otras leyes para determinar esta validez no parece posible; en especial, debe descartarse la

la necesaria colaboración que debe darse entre los sistemas legales. Esta opinión, sin embargo no tiene respaldo en las normas legales chilenas.

134 Arts. 8, 10 Convenio de Roma, de 1980; arts. 10, 12 Reglamento Roma I, del 2008; arts. 12, 14 Convención de México, de 1994; Informe Giuliano y Lagarde (1980) pp. 32-33; Lando (1976). pp. 93-124; Nygh (1999) p. 123; Plender y Wilderspin (2009) pp. 393-429.

135 El Convenio de Roma -arts. 9 (5) y (6) - y el Reglamento Roma I -arts. 11(4) y (5)- exceptúan de esta regla a los contratos de consumidores y a aquellos relativos a inmuebles.

136 Art. 9 Convenio de Roma, de 1980; art. 11 Reglamento Roma I, del 2008; art. 13 Convención de México, de 1994, art. 124 Ley Federal Suiza de Derecho Internacional Privado.

137 Lando (1976) pp. 97-102; Rabel (1947) pp. 485-491.

138 Lando (1976) pp. 97-98; Loussouarn et al. (2004) pp. 485-487; Nygh (1999) p. 127.

139 Art. 9 Convenio de Roma, de 1980; art. 11 Reglamento Roma I, del 2008; art. 13 Convención de México, de 1994; art. 124 Ley Federal Suiza de Derecho Internacional Privado; art 1181 Código Civil Argentino.

140 Arts. 14, 17, 1027 Código Civil; art. 80 Ley de Matrimonio Civil, del 2004. Ver también Charles Semond y Co. con A. y R. Falabella y Co. (1927); Ferrer con Banco Español de Chile (1931) y Albónico (1943) p. 152; Etcheberry (1960) p. 55; Domínguez (1966) p. 272; Guzmán y Millán (1973) p. 837; Ramírez (1990) p. $117,135$. 
referencia a la ley elegida por las partes ya que su ámbito de aplicación se reduce a los efectos del contrato ${ }^{141}$.

\section{Formación y validez esencial del contrato}

Hay acuerdo creciente en el derecho comparado en considerar que los requisitos de formación y validez de un contrato están determinados por la ley elegida por las partes, considerada como la ley putativa del contrato ${ }^{142}$. Sin embargo, cuando se discute la existencia misma del consentimiento, algunos sistemas legales permiten también la referencia a la ley de la residencia habitual o del asiento de los negocios de la parte que alega no haber consentido ${ }^{143}$.

Aunque la ley elegida por las partes es quien determina en primer lugar si un contrato es materialmente válido, el contrato debe cumplir también con las normas imperativas de validez del foro y respetar su orden público. Además, en algunos sistemas legales se exige que cumpla con las normas imperativas de la ley del lugar de cumplimiento si esas normas declaran el cumplimiento del contrato ilegal ${ }^{144}$.

En Chile, la jurisprudencia y la doctrina, utilizando los mismos argumentos dados para la validez formal, consideran que el Código Civil somete la validez esencial de un contrato a la ley del lugar de celebración, sin perjuicio de la aplicación de las normas imperativas chilenas ${ }^{145}$.

Esta solución chilena resulta inadecuada cuando las leyes que gobiernan la validez esencial y los efectos del contrato, dos aspectos relacionados entre sí, aportan soluciones contradictorias; por ejemplo, cuando la ley del lugar de celebración determina que un contrato es inválido porque contiene una cláusula de limitación de responsabilidad que la ley que gobierna los efectos del contrato declara válida y eficaz. Por esto, parece más conveniente la solución del derecho comparado que somete ambos aspectos a la misma ley; la ley chilena podría modificarse para adoptar esta solución.

Además, como ya se dijo al hablar de la validez de la cláusula de elección de ley ${ }^{146}$, someter la validez formal y esencial del contrato a la ley del lugar de celebración parece inconveniente y anticuado por otras razones: el lugar de celebración es, hoy en día, muchas veces accidental para las partes y puede no tener otra conexión con ellas o el contrato que justifique la aplicación de su ley. Este lugar es también a veces difícil de determinar, especialmente en contratos inter absentes ${ }^{147}$ : estos contratos se celebran por un intercambio de

141 Art. 16 Código Civil; art. 113 Código de Comercio.

142 Art. 8 Convenio de Roma, de 1980; art. 10 Reglamento Roma I, del 2008; art. 12 Convención de México, de 1994; art. 116 Ley Federal Suiza de Derecho Internacional Privado; Lando (1976) pp. 104-105; LoussouARN et al. (2004) pp. 508-509.

143 Art. 8 Convenio de Roma, de 1980; art. 10 Reglamento Roma I, del 2008; art. 12 Convención de México, de 1994; Informe Giuliano y Lagarde (1980) p. 28; Lando (1976) pp. 102-106.

144 Arts. 7, 8 Convenio de Roma, de 1980; arts. 9, 10 Reglamento Roma I, del 2008; arts. 11, 12 Convención de México, de 1994; arts. 17-19 Ley Federal Suiza de Derecho Internacional Privado; Lando (1976) pp. 107-110.

145 Ver Ferrer con Banco Español de Chile (1931) y Etcheberry (1960) pp. 57-58; Fabres (1908) Vol. I pp. 166-167; Guzmán y Millán (1973) pp. 848-850; Ramírez (2010) pp. 135-136.

146 Ver supra 2.2. A. 2.

147 Los abogados chilenos afirman que los contratos internacionales son en su mayoría inter absentes y suscritos 
firmas por fax o correo electrónico entre las partes y son precedidos de complejas negociaciones y contraofertas que hacen difícil identificar la parte que acepta la oferta final y cuya residencia, según la ley chilena, determina el lugar de celebración del contrato ${ }^{148}$.

\section{Capacidad para contratar}

La mayoría de los sistemas legales excluyen la capacidad para contratar del ámbito de la ley elegida por las partes. La capacidad de las personas naturales se somete comúnmente a su ley personal -ya sea esta su ley nacional o la de su domicilio-, o a la ley del lugar de celebración del contrato, o a la ley que rige al contrato determinada por las normas de conflicto del foro ${ }^{149}$. La capacidad de las sociedades o corporaciones se rige normalmente por la ley del lugar de su constitución o registro ${ }^{150}$.

La inclusión de la capacidad dentro del ámbito de la ley elegida ha sido rechazada porque permitiría a un menor o incapaz conferirse capacidad a sí mismo eligiendo una ley para gobernar el contrato que se la otorgue. Este mismo razonamiento ha llevado a desechar la ley del lugar de cumplimiento del contrato como ley exclusiva para determinar la capacidad contractual ${ }^{151}$.

La doctrina y la jurisprudencia abogan por someter la capacidad de personas naturales y jurídicas para celebrar contratos comerciales a la ley que gobierna el contrato, sea esta elegida o no ${ }^{152}$. Se argumenta que en estos contratos la incapacidad se alega muy raramente y que las normas imperativas del foro, que son siempre aplicables, pueden prestar protección suficiente a quien lo necesite.

En Chile, la capacidad para contratar de personas naturales y jurídicas se excluye del ámbito de la ley elegida. Esta capacidad parece estar gobernada exclusivamente por la ley del lugar de celebración del contrato $^{153}$. Esta regla puede inferirse para contratos celebrados en Chile, de la norma general del Código Civil que somete a todos los habitantes a la ley chilena ${ }^{154} \mathrm{y}$, para contratos celebrados en el extranjero, de las normas que someten la capacidad para realizar ciertos actos específicos en el extranjero a la ley del lugar de celebración ${ }^{155}$. Hay,

por medio del intercambio de firmas por fax o e-mail. Además estos abogados tienden a considerar que el lugar de celebración del contrato es irrelevante en la determinación de la ley que lo gobierna, especialmente cuando se ha incluido en el contrato una cláusula de elección de ley. Expresaron esta opinión en la entrevista ver supra $\mathrm{N}^{\circ} 75$.

148 Art. 104 Código de Comercio.

149 Art. 1 (2) Convenio de Roma, de 1980; art. 1 (2) Reglamento Roma I, del 2008; art. 5 a), f) Convención de México, de 1994; arts. 21, 35 Ley Federal Suiza de Derecho Internacional Privado; art. 7 (1) EGBGB - Ley Introductoria del Código Civil Alemán; art. 23 (1) Ley Italiana de Derecho Internacional Privado de 1995; art. 3 (3) Código Civil Francés; Cheshire y North (1999) pp. 592-595; Lando (1976) pp. 93-97; Nygh (1999) pp. 124-126; Plender y Wilderspin (2009) pp. 101-103.

150 Arts. 21, 35 Ley Federal Suiza de Derecho Internacional Privado; art. 23 (1) Ley Italiana de Derecho Internacional Privado, de 1995.

151 Cheshire y North (1999) p. 593.

152 Lando (1976) pp. 96-97; NyGH (1999) p. 126.

153 Ver Ferrer con Banco Español de Chile (1931) relativa a la capacidad de un agente contratando en España; Etcheberry (1960) pp. 37-39; Ramírez (2010) pp. 135-136.

154 Art. 14 Código Civil. Ver también Etcheberry (1960) p. 37; Guzmán (1997) pp. 453-456; Villarroel y Villarroel (1988) pp. 347-349.

155 Art. 1027 Código Civil; art. 80 Ley de Matrimonio Civil, del 2004. La mayoría de la doctrina y jurispru- 
sin embargo, una excepción pues la capacidad del chileno para celebrar contratos en el extranjero que vayan a tener efecto en Chile, se rige siempre por la ley chilena ${ }^{156}$.

Esta solución no parece apropiada: determinar la capacidad exclusivamente conforme a la ley del lugar de celebración parece, hoy en día, inadecuado porque, según ya se ha mencionado, este lugar puede ser accidental y difícil de determinar especialmente en contratos inter absentes que son comunes en el comercio internacional.

\section{Efectos del contrato}

En términos generales puede entenderse que los efectos de un contrato comprenden los derechos y obligaciones que este genera para las partes, incluyendo el modo como ellos pueden afectar a terceros, y cualquier otra consecuencia producida por él, como por ejemplo, su modo de cumplimiento, las acciones por incumplimiento, y su extinción o terminación $^{157}$. Los sistemas legales coinciden en someter estos efectos a la ley elegida por las partes, sin perjuicio de la aplicación de las normas imperativas del foro y, en el caso del modo de ejecución, opcionalmente de las normas de la ley del lugar de ejecución ${ }^{158}$.

En Chile, estos efectos están también regidos por la ley elegida por las partes, sin perjuicio de la aplicación de las normas imperativas del foro ${ }^{159}$. Así, el Código de Comercio expresamente los somete a la ley elegida por las partes ${ }^{160}$ y la doctrina extiende esta solución por analogía, a los contratos civiles y a los contratos estatales gobernados por el Decreto Ley $2.349^{161}$.

\section{Interpretación del contrato}

Se acepta comúnmente que la interpretación de un contrato está regida por la ley que lo gobierna, es decir, por la ley elegida, cuando ha habido una elección de ley ${ }^{162}$. Así

dencia afirma que la capacidad para celebrar contratos en el extranjero está regida por la ley del lugar de celebración pero esta conclusión es disputada por algunos autores porque no existen normas legales claras al respecto. Ver Etcheberry (1960) pp. 37-39; Villarroel y Villarroel (1988) pp. 341-374.

156 Art. 15 no 1 Código Civil. Ver también Etcheberry (1960) p. 37.

157 Plender y Wilderspin (2001) pp. 215-216. Los "efectos" de los contratos han sido definidos por los tribunales chilenos como los derechos y obligaciones que el contrato hace nacer para las partes; incluyen todos los aspectos del contrato a excepción de su validez formal y esencial, ver Ferrer con Banco Español de Chile (1931).

158 Art. 10 Convenio de Roma, de 1980; art. 12 Reglamento Roma I, del 2008; art. 14 Convención de México, de 1994; Art. 116, 125 Ley Federal Suiza de Derecho Internacional Privado; Restatement, Second, Conflict of Laws $\$$ 187, comment a); Section 1-105 Uniform Commercial Code; art. 2095 Código Civil Peruano, art. 29 Ley Venezolana de Derecho Internacional Privado; Informe Giuliano y Lagarde (1980) pp. 32-33; Lando (1976) p. 116; Loussouarn et al. (2004) pp. 510-517.

159 Ver arts. 16 Código Civil, art. 113 Código de Comercio y art. 1 Decreto Ley 2.349, de 1978; Ramírez (2010) p. 136. Los autores consideran que el artículo 16 del Código Civil ordena imperativamente la aplicación de la ley chilena a los contratos sobre bienes ubicados en Chile, ver Claro (1898) Vol. I p. 125; Etcheberry (1960) pp. 59-60; Domínguez (1966) p. 299. En contra Albónico (1943) pp. 144-147; Ramírez (2010) pp. 118-120.

160 Art. 113 Código de Comercio.

161 Ver supra 2.I. B. respecto de la autonomía de la voluntad en la ley chilena; Etcheberry (1960) pp. 58-60; Villarroel y Villarroel (1990) pp. 358, 364.

162 Art. 10 Convenio de Roma, de 1980; art. 12 Reglamento Roma I, del 2008; art. 14 Convención de México, de 1994; Informe Giuliano y Lagarde (1980) p. 32; Lando (1976) p. 114; Plender y Wilderspin (2001) p. 217 y (2009) pp. 399-406. 
esta ley elegida provee las reglas y principios para interpretarlo y determinar el significado de sus términos.

La ley chilena parece considerar la interpretación del contrato dentro del ámbito de la ley elegida por las partes. Así, puede inferirse que al autorizar a las partes a elegir la ley que gobierna los efectos de un contrato ${ }^{163}$, subentiende que será la ley elegida la que proveerá las reglas, principios y definiciones para interpretar y determinar esos efectos. Otros aspectos del contrato que están regidos por otras leyes -las formalidades, formación y validez esencial- deben ser interpretados de acuerdo a las leyes que los rigen. Esta solución parece inapropiada: tener que interpretar un contrato utilizando diversas leyes hace su interpretación más difícil e incierta y aumenta el riesgo legal para las partes. Por ello, sería recomendable modificar la ley chilena para someter los principales aspectos del contrato a una única ley, la elegida por las partes. Esto exigiría ampliar el ámbito de aplicación de esta ley a la validez formal y esencial del contrato.

\section{Los límites en el ejercicio de la autonomía}

Hay consenso en el derecho comparado de que la libertad de elegir de las partes tiene que estar sujeta a ciertos límites y los sistemas legales normalmente los incluyen. Estos límites pretenden garantizar una relación contractual justa entre las partes, evitar el fraude o la evasión de ley y proteger valores fundamentales del foro ${ }^{164}$. Ellos pueden ser impuestos por la ley del foro, la ley elegida y, eventualmente, por la ley de un tercer Estado conectada al contrato ${ }^{165}$.

La ley del foro determina la permisibilidad de la autonomía y las condiciones para ejercerla. También determina los valores básicos y principios a los que debe conformarse la ley elegida y provee las normas imperativas que van a prevalecer por sobre aquellas de la ley escogida. La ley elegida, por su parte, puede aportar restricciones adicionales a la autonomía al incluir normas imperativas y otros principios que las partes no pueden derogar. Además, la ley del foro o la elegida pueden exigir la aplicación de las normas imperativas de un tercer Estado conectado con el contrato ${ }^{166}$.

Entre los límites más comunes impuestos a la autonomía están: autorizarla solo para contratos internacionales, exigir una conexión entre la ley elegida y el contrato, restringir la elección a una ley estatal, exigir que la elección no sea contraria al orden público del foro o hecha con fraude a esa ley, exigir el respeto de las normas imperativas del foro y asegurar la protección de la parte contratante más débil ${ }^{167}$. La ley chilena sigue esta tendencia y contiene, como veremos, algunas de estas limitaciones.

\footnotetext{
163 Art. 113 Código de Comercio, art 1 Decreto Ley 2.349, de 1978.

164 Ver Lando (1976) pp. 33-43 y (1985) pp. 286-303; Kassis (1993) pp. 175-186; Loussouarn et al. (2004) pp. 514-517; Nygh (1999) Capítulo 3.; Plender y Wilderspin (2009) pp. 159-166; Rabel (1947) pp. 394429; SCOLEs et al. (2004) pp. 965-987.

165 Art. 7 Convenio de Roma, de 1980; art. 9 Reglamento Roma I, del 2008; art. 11 Convención de México, de 1994; arts. 17-19 Ley Federal Suiza de Derecho Internacional Privado; Restatement, Second, Conflict of Laws S187, comment a); Section 1-105 Uniform Commercial Code.

166 Ver infra 2.2. C. 4-5.

167 Ver Nygh (1999) Capítulo 3; Plender y Wilderspin (2009) pp. 159-166; Scoles et al. (2004) pp. 953954, 965-987.
} 


\section{Carácter internacional del contrato}

La restricción de la autonomía de la voluntad a contratos internacionales o interestatales, en el caso de Estados federales, es ampliamente aceptada en muchos sistemas legales ${ }^{168}$; sin embargo, hay importantes excepciones, como por ejemplo, la de los países miembros de la Unión Europea que aceptan la autonomía para contratos puramente nacionales ${ }^{169}$.

Los sistemas legales utilizan una variedad de factores para caracterizar un contrato como internacional, entre ellos: el hecho de que las partes tengan su domicilio, residencia habitual, o asiento principal de sus negocios en países distintos, el hecho de que el lugar de celebración o cumplimiento del contrato sea en el extranjero o el hecho de que el pago deba hacerse en moneda extranjera o de que el contrato tenga un impacto económico en diversos países ${ }^{170}$. Hay consenso, sin embargo, de que un contrato debe considerarse internacional cuando tiene alguna conexión objetiva con más de un país; esto excluye la posibilidad de que las partes acuerden dar a un contrato puramente nacional el carácter de internacional si no existe en él ningún elemento que lo conecte con otro país. Así, en muchos sistemas legales, la posibilidad de ejercitar la autonomía depende de que el contrato tenga los conectores que la ley del foro exige para caracterizarlo como internacional ${ }^{171}$.

En Chile, la autonomía de la voluntad está restringida a los contratos internacionales ya que la elección de ley extranjera está prohibida para contratos puramente nacionales. En efecto, los amplios términos en que el Código Civil somete a toda persona y acto jurídico celebrado o que va a tener efecto en Chile a la ley chilena, permite concluir que los contratos puramente nacionales están regidos necesariamente por esta ley ${ }^{172}$. Además, la aceptación en el Código de Comercio de elecciones de ley para los contratos comerciales celebrados en el extranjero para cumplirse en Chile parece reforzar la conclusión de que la autonomía solo puede ejercitarse en contratos internacionales ${ }^{173}$. Este requisito está expresamente establecido para los contratos públicos gobernados por el Decreto Ley 2.349 y

168 Art. 1 Convención de México, de 1994; Restatement, Second, Conflict of Laws $\$ 187$, comment a), art. 116 Ley Federal Suiza de Derecho Internacional Privado; ver también Lando (1976) p. 34; Nygh (1999) p. 47; RüHL (2007) p. 159-160.

169 El Convenio de Roma, de 1980 y el Reglamento Roma I, del 2008 permiten la autonomía para contratos internacionales o no "en las situaciones que impliquen un conflicto de leyes", la versión inglesa de ambas normas lo expresa con más claridad al referirse a contratos "involving a choice between the laws of different countries" (art. 1). Así, ambas normas permiten elegir una ley extranjera para contratos puramente nacionales pero, cuando todos los elementos del contrato están localizados en el momento de la elección en un país distinto de aquel cuya ley se elige, la elección de las partes no impedirá la aplicación de las disposiciones imperativas de la ley de ese país que no pueden excluirse mediante un acuerdo o derogarse mediante un contrato (art. 3 (3) Convenio de Roma, de 1980 y Reglamento Roma I, del 2008). Ver Nygh (1999) pp. 54-55; Plender y Wilderspin (2009) pp. 159-166, RüHL (2007) pp. 159-160.

170 Art 1 (1) Convención de Viena, de 1980; art. 1 Convención de México, de 1994, art 1 (a) Protocolo de Buenos Aires, de 1994; ver Lando (1976) pp. 34-35; Kassis (1993) pp. 71-91; Nygh (1999) pp. 48-55.

171 Ver Lando (1976) pp. 34-35; NyGH (1999) pp. 48-55. Esta exigencia no se aplica a los contratos conectados con países de la UE y gobernados por el Convenio de Roma, de 1980 o el Reglamento Roma I, del 2008.

172 Ver Ramírez (2010) p. 133.

173 Arts. 14, 16 Código Civil; art. 113 Código de Comercio. Ver también Albónico (1943) p. 143; EтchebeRRY (1960) p. 58; Maluenda (1998) p. 60. 
para los contratos de compraventa internacional de mercaderías gobernados por la Convención de Viena de $1980^{174}$.

En Chile no existe definición o criterio adecuado para determinar cuándo un contrato es internacional ${ }^{175}$. Una interpretación literal de las normas del Código Civil y de Comercio permite caracterizar un contrato como internacional cuando ha sido celebrado en el extranjero para cumplirse en Chile ${ }^{176}$; una interpretación analógica de estas mismas normas amplía esta caracterización a contratos celebrados en un Estado para ser cumplidos en otro. Ambas caracterizaciones son, sin embargo, demasiado restringidas y ajenas la práctica comercial en donde no es inusual que un contrato internacional sea celebrado y cumplido en un mismo Estado. Un mejor criterio de caracterización -el hecho de que las partes tengan el asiento de sus negocios en países diferentes- puede encontrarse en normas más recientes relativas a contratos públicos y de compraventa internacional de mercaderías ${ }^{177}$; es incierto, sin embargo, si los jueces aplicarán esta caracterización a otros contratos o aceptarán otros elementos objetivos para caracterizar un contrato como internacional por la inexistencia de normativa y de jurisprudencia vinculante al respecto ${ }^{178}$. En suma, las normas legales en vigor parecen establecer una caracterización de contrato internacional demasiado rígida y anticuada, que no se concilia bien con la práctica legal y que, por ello, necesita de modificación.

\section{Conexión del contrato con la ley elegida}

En el pasado, las legislaciones prescribían que las partes debían elegir una ley de algún modo conectada con el contrato ${ }^{179}$. Esta concepción ha sido progresivamente abandonada y hoy se acepta que es razonable dejar la elección al buen sentido de las partes contratantes ${ }^{180}$. De este modo, la elección de una ley sin conexión con el contrato se acepta en la mayoría de los sistemas legales a menos que esta elección esté prohibida por una norma imperativa o el orden público del foro ${ }^{181}$. Esta solución resulta coherente con el principio de autonomía de la voluntad. En Chile, se sigue esta tendencia: la doctrina y los abogados

\footnotetext{
174 Art. 1 Decreto Ley 2.349, de 1978; art. 1 (1) Convención de Viena, de 1980.

175 Ramírez (2010) pp. 129-130, 134-135.

176 Art. 16 Código Civil; art. 113 Código de Comercio.

177 Art. 1 Decreto Ley 2.349, de 1978; art. 1 (1) Convención de Viena, de 1980.

178 En State Street Bank and Trust Company con Inversiones Errázuriz Ltda. y Otros (2007) la Corte Suprema parece considerar otros elementos para determinar el carácter internacional del contrato como la necesidad de aplicar los ordenamientos jurídicos de Estados diferentes, el que las sociedades partes del contrato estén constituidas en diferentes países y regidas por sus leyes, que las consecuencias del contrato se produzcan en distintos países y que en el contrato se haga referencia a leyes de distintos países; sin embargo, en definitiva, la Corte determina que el contrato es internacional porque se celebró fuera de Chile (en Nueva York).

179 Lando (1976) pp. 35-36; NyGH (1999) pp. 55-57.

180 Esta libertad de elección es otorgada, entre otras, por el art. 3 (1) Convenio de Roma, de 1980 y Reglamento Roma I, del 2008; art. 7 Convención de México, de 1994; art. 116.1 Ley Federal Suiza de Derecho Internacional Privado.

181 Lando (1976) p. 37; Nygh (1999) p. 60; Scoles et al. (2004) pp. 953, 980-981. Una excepción es la del Restatement, Second, Conflict of Laws $\$$ 187, comment a), al respecto ver RüHL (2007) pp. 160-164.
} 
nacionales entienden que la legislación acepta elecciones de leyes sin conexión con el contrato $^{182}$.

3. Elección de un sistema legal estatal o de la costumbre internacional

Algunos sistemas legales restringen la autonomía a la posibilidad de elegir la ley de un Estado y excluyen la posibilidad de elegir otras normas a-nacionales como las de la lex mercatoria ${ }^{183}$ o los usos o principios comerciales internacionales ${ }^{184}$. Se discute la conveniencia de esta restricción sin que se haya llegado a un consenso al respecto ${ }^{185}$. Sin embargo, la utilización de usos y principios comerciales internacionales y de la lex mercatoria está siendo progresivamente aceptada en el comercio internacional y ha obtenido reconocimiento en algunos sistemas legales ${ }^{186}$.

El argumento principal en pro de esta restricción es que una ley estatal es la única apta para gobernar un contrato ya que solo ella puede hacerlo nacer, definir exhaustivamente los derechos y obligaciones de las partes y proveer un sistema para hacerlo exigible ${ }^{187}$. Además, se argumenta que el contenido de la lex mercatoria es demasiado incierto e incompleto para proveer una ley que verdadera y completamente gobierne a un contrato ${ }^{188}$; ello sin perjuicio de que esta lex pueda ser incorporada por referencia dentro de él ${ }^{189}$.

Quienes rechazan esta restricción dicen que debe autorizarse que las partes elijan una ley a-nacional como la lex mercatoria o los principios del derecho comercial internacional para gobernar un contrato porque esta lex y/o principios pueden proveer normas válidas, adecuadas, modernas y suficientes para ello ${ }^{190}$. Argumentan que esto es usual en el arbitraje internacional donde la elección de usos y principios comerciales ha sido común y crecientemente aceptada ${ }^{191}$. Agregan además que resulta inconsistente aceptar estas elecciones en juicios arbitrales y rechazarlas en juicios ante tribunales ordinarios, especialmente, si se tiene en cuenta que la ejecución de las sentencias arbitrales debe ser ordenada por estos tribu-

182 Art. 16 Código Civil; 113 Código de Comercio; art. 1 Decreto Ley 2.349, de 1978. Los abogados entrevistados sostuvieron unánimemente esta opinión: ver supra Nº75. Ver Villarroel y Villarroel (1990) p. 359 donde estos autores, aunque aceptando la posibilidad de la elección de una ley sin conexión al contrato, afirman que las normas imperativas de la ley más conectada al contrato se le aplicarán siempre.

183 Lex mercatoria puede definirse de modo amplio como una fuente de ley a-nacional constituida por costumbres, usos y principios creados por los operadores del comercio internacional, que reemplazan o suplementan las normas legales de origen estatal. Al respecto ver NyGH (1999) pp. 61-62, 177-191.

184 Este parece ser el caso de la Convención de Roma, de 1980 y del Reglamento Roma I, del 2008, vigentes en los países de la UE y del Restatement Second Conflict of Laws \$ 187 y Uniform Commercial Code \$ 1-105, S 1-301 en EEUU. Ver Cheshire y North (1999) pp. 559-560; Fernández (2004) p. 36; Kassis (1993) pp. 373-384; Plender y Wilderspin (2001) pp. 56-57, (2009) pp. 136-138: RüHL (2007) pp. 164-167.

185 Kassis (1993) pp. 373-393; Plender y Wilderspin (2009) pp. 136-139.

186 Art 11 Convención de México, de 1994; art. 28 (1) Ley Modelo UNCITRAL de Arbitraje Internacional, art. 31 Ley Venezolana de Derecho Internacional Privado; Leible (2011) pp. 226-228; Nygh (1999) pp. 61-62.

187 Nygh (1999) p. 61 y Cap. 8 donde se hace un amplio estudio de la lex mercatoria y de su reconocimiento a nivel internacional.

188 Kassis (1993) p. 379; Nygh (1999) pp. 61-62; Plender y Wilderspin (2009) p. 137.

189 Kassis (1993) pp. 380-381.

190 Juenger (1994) pp. 391-392.

191 Por ejemplo, art. 28 (1) Ley Modelo UNCITRAL de Arbitraje Internacional; Nygh (1999) pp. 191-198. 
nales. Por eso, es más lógico que estas elecciones sean también aceptadas por los tribunales ordinarios ${ }^{192}$.

Cualquiera sea la opinión respecto a esta restricción, hay consenso en considerar que la permisibilidad y condiciones para elegir la lex mercatoria o los usos del comercio internacional depende de la ley del foro y, por ello, de que no es totalmente independiente de un sistema de ley estatal ${ }^{193}$.

En la legislación chilena, la autonomía está restringida a la elección de una ley estatal vigente. Las partes no parecen estar autorizadas para elegir la lex mercatoria o los usos comerciales internacionales para regir un contrato, sin perjuicio de su derecho a incorporarlos por referencia dentro de él. Esta exigencia de elección de ley estatal puede inferirse de las normas sobre ley reguladora de contratos que parecen referirse todas a una ley estatal ${ }^{194} \mathrm{y}$ de las normas que establecen que las costumbres y usos comerciales solo se aplican para suplir la ley estatal cuando la ley expresamente lo autoriza o cuando existe un vacío legal ${ }^{195}$.

4. Elección no contraria al orden público o fraudulenta

La autonomía está también sujeta al requisito de que la elección de las partes no puede ser contraria al orden público del foro ni hecha con la intención fraudulenta de evadir sus normas ${ }^{196}$. Esta restricción busca proteger normas o principios legales básicos del foro y asegurar el cumplimiento de sus normas imperativas cuando han sido fraudulentamente evadidas ${ }^{197}$.

El concepto de orden público garantiza en todos los sistemas legales la protección de los principios legales básicos del foro ${ }^{198}$. Así, cuando una norma de la ley extranjera o una estipulación de las partes contradice estos principios básicos, los jueces pueden desestimarla como contraria al orden público ${ }^{199}$.

El remedio del fraude a la ley corrige una elección fraudulenta de ley en algunos sistemas legales ${ }^{200}$. El fraude a la ley pretende dejar sin efecto una elección de ley cuando las partes han manipulado un factor de conexión para obtener una ventaja denegada o prohibida por la ley del foro o por la ley que, sin mediar elección, gobernaría el contrato ${ }^{201}$. Se aplica cuando

\footnotetext{
192 Kassis (1993) pp. 378-379.

193 Leible (2011) p. 226; Nygh (1999) p. 175.

194 Art. 16 Código Civil; arts. 4-6, 113 Código de Comercio; art. 1 Decreto Ley 2.349, de 1978. La doctrina no trata este asunto pero parece entender que la posibilidad de elección se limita a una ley estatal: Albónico (1943) pp. 142-143; Maluenda (1998) p. 66; Villarroel y Villarroel (1990) pp. 358-359.

195 Art. 2 Código Civil; arts. 4-6 Código de Comercio.

196 Arts. 7 y 16 Convenio de Roma, de 1980; arts. 9 y 21 Reglamento Roma I, del 2008; arts. 11 y 18 Convención de México, de 1994; arts. 17-19 Ley Federal Suiza de Derecho Internacional Privado; Restatement, Second, Conflict of Laws $\$ 187$, comment a); Lando (1976) pp. 38-39; Leible (2011) p. 232; NyGH (1999) pp. 66-69; SCOLES et al. (2004) pp. 956-974.

197 Lando (1976) pp. 38-39; NyGH (1999) pp. 66-69.

198 Lando (1976) pp. 38-39; Nygh (1999) p. 67; Rabel (1947) pp. 549-590; Villarroel y Villarroel (2004) pp. 83-89.

199 Villarroel y Villarroel (2004) pp. 87-88.

200 Lando (1976) pp. 36-37; Nygh (1999) pp. 68-69 Villarroel y Villarroel (2004) pp. 91-96 .

201 Nygh (1999) p. 68.
} 
se acredita que la elección de las partes fue fraudulenta y realizada con una intención concertada de evasión de ley y, algunas veces, de dañar a terceros ${ }^{202}$. La conveniencia de aplicar este remedio a los contratos se critica acertadamente por su inconsistencia con el principio de la autonomía de la voluntad, que reconoce a las partes el derecho de elegir libremente la ley que gobierna sus contratos ${ }^{203}$. Además, su aplicación se considera innecesaria porque los efectos nocivos de una elección fraudulenta de ley pueden corregirse adecuadamente con la protección del orden público del foro y de sus normas imperativas ${ }^{204}$.

En cualquier caso, los jueces deben aplicar las restricciones del orden público y del fraude a la a ley excepcionalmente ya que un celo excesivo en el uso de estas restricciones puede comprometer la libertad contractual y la autonomía de la voluntad en sí ${ }^{205}$. Además podría promover el forum shopping y poner en peligro la certeza y predictibilidad de las decisiones judiciales.

En Chile, la ley elegida no es aplicable cuando viola los principios básicos de la ley chilena o se elige con la intención de evadir fraudulentamente sus normas. Aunque no existe norma general al respecto, la protección de estos principios básicos se ha deducido de las normas que declaran inexistente o nulo los contratos que contienen un objeto o causa contraria al orden público interno chileno o a la moralidad ${ }^{206}$. La Corte Suprema ha aplicado esta solución en algunos casos y ha sostenido que "constituyen disposiciones de orden público en la esfera del Derecho Privado las normas de la legislación que gobiernan el estado y la capacidad de las personas, sus relaciones de familia y, en general, aquellas reglas dictadas en interés de la sociedad y que resguardan la integridad de las instituciones jurídicas básicas", todas las cuales no pueden ser desestimadas por las partes ${ }^{207}$. Del mismo modo, la ley chilena no tiene norma que sancione el fraude a la ley, pero la doctrina y jurisprudencia están de acuerdo en que nadie puede tomar ventaja de su propio fraude para evadir el cumplimiento de la ley chilena. De este modo, cuando la protección del orden público es incapaz de corregir una elección de ley fraudulenta, esta elección puede ser desestimada usando el remedio del fraude a la ley ${ }^{208}$.

5. Respeto de las normas imperativas del foro, de la lex causae o de un tercer Estado Normas imperativas del foro, de la lex causae y de un tercer Estado pueden restringir la autonomía de la voluntad dejando sin efecto normas de la ley elegida por las partes ${ }^{209}$.

202 LaNdo (1976) pp. 36-37; NyGH (1999) p. 68.

203 NyGh (1999) p. 68.

204 Nygh (1999) p. 68.

205 Rabel (1947) pp. 550, 552.

206 Arts. 1461, 1467 Código Civil. El Código de Bustamante establece que las partes no pueden evadir ciertas normas del foro protectoras de su orden público: arts. 3-II, 175, 179, 194-195, 197, 246, 254, 257. Ver también Ducci (2002) pp. 292-293, 297; León (1963) pp. 81-84; Ramírez (2010) pp. 83-85.

207 Roumié con Pate Perrin (1960). Ver también Guzmán (1997) pp. 392-393.

208 Ver Guzmán (1997) pp. 423-426; Ramírez (2010) pp. 85-87; Villarroel y Villarroel (1990) p. 359.

En relación al fraude a la ley y las personas jurídicas, ver Lyon (2003) pp. 66-70.

209 Respecto de la naturaleza, función y efectos de las normas imperativas ver NyGH (1999) Capítulo 9: VILLArroel y Villarroel (2004) Capítulo 14. Ver también el comentario al art. 7 del Convenio de Roma, de 1980 en Informe Giuliano y Lagarde (1980) pp. 26-28 y Leible (2011) p.p. 228-231 en relación al art. 9 del Reglamento Roma I, del 2008. 
Estas son normas imperativas en el ámbito internacional que no pueden ser dejadas sin efecto ni reemplazadas por las normas de otro sistema legal ${ }^{210}$. Ellas excluyen la ley elegida por las partes y proveen una solución sustancial para el problema que $\operatorname{tratan}^{211}$. Las partes no pueden, por tanto, declararlas inaplicables por medio de la elección de una ley extranjera, aunque el contrato sea internacional ${ }^{212}$. Estas normas difieren de las normas imperativas en el ámbito interno, las que no pueden ser dejadas sin efecto en un contrato puramente nacional, pero sí pueden ser reemplazadas por la elección de una ley extranjera en un contrato internacional ${ }^{213}$.

Las normas imperativas o "leyes de policía" tienden a proteger grupos particulares de personas (por ejemplo, consumidores y empleados) o el sistema económico nacional (por ejemplo, normas antimonopolio, prohibiciones de importación o exportación, control de precios, restricciones al tipo de cambio) o valores morales (por ejemplo matrimonio monógamo y heterosexual, no discriminación) o el interés público (por ejemplo, restricciones al dominio) y pueden ser especialmente relevantes en algunos tipos de contratos ${ }^{214}$. Su efecto es desplazar la ley elegida parcialmente ya que ella sigue siendo aplicable respecto de las materias no regladas por estas normas ${ }^{215}$.

En el derecho comparado, las normas imperativas del foro se aplican siempre a un contrato y dejan sin efecto las normas de la ley elegida que se les oponen. Lo mismo sucede con las normas imperativas de la lex causae o de la ley elegida, que se aplican siempre, salvo que se opongan a las normas imperativas o al orden público del foro o hayan sido derogadas por las partes ${ }^{216}$. Por el contrario, las normas imperativas de la ley de un tercer Estado conectado al contrato pueden eventualmente aplicarse, a discreción de los jueces, cuando la ley del foro o la lex causae autoricen su aplicación ${ }^{217}$. En todo caso, hay consenso en la doctrina de que las normas imperativas deben ser interpretadas restrictivamente y ser aplicadas excepcionalmente para no poner en peligro la certeza y predictibilidad jurídicas ${ }^{218}$. Esto se aplica especialmente respecto de las normas imperativas de la ley de un tercer Estado conectada al contrato ${ }^{219}$.

${ }_{210}$ El Convenio de Roma, de 1980 y el Reglamento Roma I, del 2008 las llaman leyes de policía: ver arts. 7 y 9 , respectivamente.

211 Nygh (1999) p. 202.

212 Ver por ejemplo, art. 7 Convenio de Roma, de 1980; art. 9 Reglamento Roma I, del 2008; art. 11 Convención de México, de 1994. Ver también Plender y Wilderspin (2001) p. 106 y (2009) pp. 333-342.

213 Ver por ejemplo, art. 3 (3) Convenio de Roma, de 1980; arts. 3 (3), 3 (4) Reglamento Roma I, del 2008. Ver también Nygh (1999) p. 199 y Plender y Wilderspin (2009) pp. 159-161.

214 Por ejemplo, en contratos de consumidores, de trabajo, y de seguros. Al respecto ver: Lando (1976) pp. $37-$ 38; Nygh (1999) pp. 203-205; Plender y Wilderspin (2009) p. 159; Rühl (2007) pp. 167-175

215 Nygh (1999) p. 203.

216 Ver por ejemplo, art. 7 Convenio de Roma, de 1980; art. 9 Reglamento Roma I, del 2008; art. 11 Convención de México, de 1994; art. 18 Ley Federal Suiza de Derecho Internacional Privado.

217 Ver por ejemplo, art. 7 Convenio de Roma, de 1980; art. 9 (3) Reglamento Roma I, del 2008; art. 11 Convención de México, de 1994. Ver también Informe Giuliano y Lagarde (1980) p. 27; Plender y Wilderspin (2009) pp. 343-351; Nygh (1999) pp. 217-226.

${ }^{218}$ Ver Considerando (37) Reglamento Roma I, del 2008; Nygh (1999) pp. 211-212.

219 Art. 7 Convenio de Roma, de 1980; art. 9 (3) Reglamento Roma I, del 2008; art. 11 Convención de México, de 1994. Ver también Informe Giuliano y Lagarde (1980) p. 27. El Reglamento Roma I, del 2008 res- 
La ley chilena no contiene indicaciones respecto a las normas imperativas, pero la autonomía parece estar limitada por las normas imperativas del foro y las de la ley elegida. La obligación de respeto de las normas imperativas del foro es una consecuencia obvia del principio de territorialidad que inspira la legislación, el que da prioridad a estas normas sobre cualquier otra ley aplicable al contrato ${ }^{220}$. Las normas imperativas de la ley elegida se aplican siempre a menos que contradigan a las normas imperativas del foro o que las partes las hayan derogado por medio del ejercicio de la autonomía material o sustantiva. Parece dudoso que se puedan aplicar al contrato las normas imperativas de la ley de un tercer Estado conectada al contrato porque la aplicación del derecho extranjero y de normas imperativas es excepcional en el derecho chileno ${ }^{221}$. Así, la Corte Suprema, en un fallo relativo a un contrato nacional, estableció que las normas legales prevalecen sobre las estipulaciones de las partes solo cuando es absolutamente claro que estas normas son imperativas y que, como tales, prevalecen sobre ellas ${ }^{222}$.

Finalmente, la ley chilena contiene algunas normas que exigen imperativamente la aplicación de la ley chilena a ciertos contratos y que, por ello, prohíben o limitan el ejercicio de la autonomía respecto de ellos. Por ejemplo, los contratos nacionales deben ser gobernados por la ley chilena ${ }^{223}$, los efectos de los contratos internacionales que se cumplen en Chile referentes a bienes inmuebles o muebles ubicados dentro del territorio deben también ser gobernados por la ley chilena ${ }^{224}$ y lo mismo sucede con los contratos de transporte marítimo si el puerto de destino está ubicado en Chile ${ }^{225}$. Además, los contratos de trabajo individual y con consumidores celebrados o cumplideros en Chile están regidos imperativamente por las leyes chilenas de tal modo que las partes no pueden elegir gobernarlos por otras leyes que contengan normas menos favorables para el trabajador o consumidor ${ }^{226}$.

\section{CONCLUSIONES}

La aceptación y tratamiento de la autonomía de la voluntad en Chile es producto más de la práctica legal que de normas legales específicas. En efecto, las cláusulas de elección de ley son normalmente incluidas en contratos internacionales conectados con Chile aunque no están adecuadamente reguladas en su legislación. Las normas chilenas autorizan las elecciones de ley exclusivamente para los contratos internacionales celebrados por el Estado y para los efectos de los contratos comerciales celebrados en el extranjero para ser cumplidos en el país, todo ello a pesar de que la autonomía es normalmente practicada en

tringe la posibilidad de aplicar las normas imperativas de la ley de un tercer Estado, a las normas imperativas de la ley del lugar de cumplimiento cuando ellas declaran el cumplimiento ilegal.

220 Arts. 14, 16 inc. $3^{\circ}$ Código Civil someten los contratos que producen efectos en Chile a la ley chilena.

221 En contra Villarroel y Villarroel (1990) p. 359. Estos autores afirman que las normas imperativas de la ley más conectada al contrato deben aplicarse por la necesaria cooperación entre los sistemas legales.

222 Ver Zolezzi y otra con Gallardo (1955).

223 Ver supra C. 1.

224 Art. 16 Código Civil.

225 Arts. 979-980 Código de Comercio.

226 Ver Ley 19.946, de 1997; arts. 1 y 5 Decreto con Fuerza de Ley No 1, del 2002; Fermandois (2001) p. 93. 
Chile más allá de este ámbito 227 . Por ello, la jurisprudencia y doctrina han debido interpretar analógicamente las normas internas sobre contratos para resolver los problemas que surgen del ejercicio de la autonomía. Esta interpretación judicial y doctrinal no tiene ni ha tenido la fuerza vinculante suficiente para garantizar la eficacia de las cláusulas de elección de ley en Chile, a pesar de ser concordante con el principio general de libertad contractual que inspira la legislación chilena.

La ausencia de normas legales regulando la autonomía y el territorialismo que inspira a las normas chilenas producen incerteza jurídica para los contratantes respecto de la eficacia de sus elecciones de ley en contratos internacionales. Esta incerteza se agudiza con la fluctuación de la jurisprudencia respecto de la aceptación o no de estas elecciones y su tendencia a aplicar imperativamente la ley chilena a los contratos que se cumplen en Chile. Parece importante y necesario disminuir esta incerteza con la dictación de normas legales que validen y regulen la práctica de la autonomía; desgraciadamente, a la fecha no hay una iniciativa legal al respecto.

La comparación de las soluciones de la ley chilena con aquellas del derecho comparado muestra que, aunque en algunos aspectos son semejantes, la aceptación de la autonomía en Chile es más limitada que en la mayoría de las legislaciones mundiales. Esta limitación es consecuencia del restringido ámbito de aplicación que la ley chilena asigna a la ley elegida por las partes. En Chile esta ley gobierna solo los efectos del contrato quedando sus otros aspectos gobernados por la ley determinada por las normas de conflicto del foro; en el derecho comparado, en cambio, la ley elegida gobierna los aspectos principales del contrato y las normas de conflicto del foro se aplican excepcionalmente, como un límite de la autonomía de las partes. Esta segunda solución permite a las partes realmente elegir normas más convenientes que aquellas determinadas por la ley del foro y les otorga mayor predictibilidad y certeza jurídica. La solución chilena, en cambio, disminuye la predictibilidad, restringe el efecto de la elección de ley hecha por las partes y somete el contrato a una pluralidad de leyes que pueden no ser deseadas o previstas por ellas. Por esta razón, parece conveniente modificar la ley chilena para ampliar el ámbito de aplicación de la ley elegida de modo que gobierne los aspectos principales del contrato. Esta modificación debiera someter la formación y validez esencial del contrato y de la cláusula de elección de ley a la ley elegida, en reemplazo de la ley del lugar de celebración que actualmente las rige. Este recurso a la ley del lugar de celebración parece particularmente inapropiado por la dificultad para determinar este lugar en los contratos inter absentes y el escaso o irrelevante vínculo que su ley puede tener con las partes o el contrato mismo.

El ejercicio efectivo de la autonomía en Chile requiere además de la dictación de otras normas de conflicto, inexistentes en su legislación; como aquellas definiendo lo que es un contrato internacional, especificando el rol de las normas imperativas o de policía del foro o de otros Estados conectados con la situación jurídica y fijando los límites a la aplicación de la ley extranjera. Estas normas son necesarias para aumentar la certeza legal para las partes contratantes; la ley chilena podría incluirlas mediante una modificación del Código Civil o bien, dictando una ley de Derecho Internacional Privado específica.

227 Art. 113 Código de Comercio; art. 1 Decreto Ley 2.349, de 1978. 


\section{BIBLIOGRAFÍA CITADA}

Albónico, Fernando (1943): El Derecho Internacional Privado ante la Jurisprudencia Chilena (Santiago de Chile, Editorial Nascimento) 282 pp.

Albónico, Fernando (1950): Manual de Derecho Internacional Privado (Santiago de Chile, Editorial Jurídica de Chile) vol. 2, 378 pp.

American Law Institute (1971) Restatement of the Law, Second, Conflict of Laws 2nd (St Paul Minnessotta).

Audit, Bernard (2006): Droit International Privé (Paris, Economica) 4ª Ed., 930 pp.

Bezanilla, Ricardo (1966): "Las Personas", en: Hamilton, Eduardo, Solución de Conflictos de Leyes y Jurisdicción en Chile (Santiago de Chile, Editorial Jurídica de Chile): pp. 17-82.

Boggiano, Antonio (1983): "International Contracts in Argentina", Rabels Zeitschrift, vol. 47: pp. 431-477.

Boggiano, Antonio (1991): International Standard Contracts. The Price of Fairness (Dordrecht, Graham \& Trotman) 339 pp.

Boggiano, Antonio (2000): Curso de Derecho Internacional Privado (Buenos Aires, Abeledo-Perrot) $2^{a}$ Ed., 1011 pp.

Cheshire, Geoffrey y North, Peter (1999): Private International Law (Londres, Butterworths) $13^{\text {va }}$ Ed., $1069 \mathrm{pp}$.

Claro, Luis (1898): Explicaciones de Derecho Civil Chileno y Comparado (Santiago de Chile, Establecimiento Poligráfico Roma) vol. 1, 501 pp.

Domínguez, Raúl (1966): "Obligaciones, Contratos y Hechos Jurídicos", en: Hamilton, Eduardo, Solución de Conflictos de Leyes y Jurisdicción en Chile (Santiago de Chile, Editorial Jurídica de Chile) pp. 266-314.

Ducci, Carlos (2002): Derecho Civil. Parte General (Santiago de Chile, Editorial Jurídica de Chile) $4^{a}$ Ed., 448 pp.

Etcheberry, Alfredo (1960): Bilateral Studies in Private International Law: American-Chilean Private International Law, No 10 (Nueva York, Oceana Publications) 96 pp.

FABRes, José Clemente (1887): "Le Droit International Privé dans la Législation du Chili", Journal de Droit International Privé, vol. 14: pp. 133-143.

Fabres, José Clemente (1908): Obras Completas de don José Clemente Fabres. Derecho Internacional Privado (Santiago de Chile, Imprenta Cervantes) vol. I, 373 pp.

Fermandois, Arturo (2001): Derecho Constitucional Económico (Santiago de Chile, Ediciones Universidad Católica de Chile) vol. 1, 252 pp.

Fernández, José Carlos (2004): "Lex mercatoria y Autonomía Conflictual en la Contratación Transnacional", Anuario Español de Derecho Internacional Privado, vol. 4: pp. 35-78.

Gesche, Bernardo, Espinosa, Ximena y Ritterhaussen, Karin (1982): Jurisprudencia y Tratados de Derecho Internacional Privado Chileno (Santiago de Chile, Editorial Jurídica de Chile) 299 pp.

Goldschmidt, Werner (1984): "La Autonomía Conflictual de las Partes, su Forma y Alcance", El Derecho, vol. 109: pp. 711-720.

Giuliano, Mario y Lagarde, Paul (1980): "Report on the Convention on the Law Applicable to Contractual Obligations", Official Journal CEE C. 282, 31-X-1980, pp. 1-50. 
Guzmán, Diego (1969): Elementos de Derecho Internacional Privado (Santiago de Chile, Editorial Jurídica de Chile) 303 pp.

Guzmán, Diego (1997): Tratado de Derecho Internacional Privado (Santiago de Chile, Editorial Jurídica de Chile) $3^{\text {a }}$ Ed., 656 pp.

Guzmán, Diego y Millán, Marta (1973): Curso de Derecho Internacional Privado (Santiago de Chile, Editorial Jurídica de Chile) 959 pp.

Hague Conference On Private International (2009): Feasibility Study on the Choice of Law in International Contracts. Report on Work Carried Out and Suggested Work Programme for the Development of a Future Instrument, Prel. Doc No7, III-2009.

Hamilton, Eduardo (1966): Solución de Conflictos de Leyes y Jurisdicción en Chile (Santiago de Chile, Editorial Jurídica de Chile) 407 pp.

Hernández-Bretón, Eugenio (2003): “Autonomía Conflictual en América Latina. Tendencias Actuales", Anuario Hispano-Luso-Americano de Derecho Internacional, vol. 16: pp. 441-471.

Juenger, Friedrich (1994): "The Inter-American Convention on the Law Applicable to International Contracts: Some Highlights and Comparisons", The American Journal of Comparative Law, vol. 42: pp. 381-393.

Kaller, Berta (1995): Nuevo Manual de Derecho Internacional Privado (Buenos Aires, Editorial Plus Ultra) $4^{a}$ Ed., 617 pp.

Kassis, Antoine (1993): Le Nouveau Droit Européen des Contrats Internationaux (Paris, Librairie Générale de Droit et de Jurisprudence) 598 pp.

Lando, Ole (1976): International Encyclopedia of Comparative Law vol. III Cap. 24: pp. 157 (Mouton, The Hague, and J.C.B. Mohr Tübingen).

Lando, Ole (1985): “The Conflict of Laws of Contracts. General Principles” en Académie de Droit International, Recueil des Cours, vol. 189: pp. 229-447.

León, Avelino (1963): La Voluntad y la Capacidad en los Actos Jurídicos (Santiago de Chile, Editorial Jurídica de Chile) $2^{a}$ Ed., 460 pp.

León, Avelino (2002a): "Reforma del Sistema Chileno de Derecho Internacional Privado" en: Kleinheisterkamp, Jan (coord.), Avances del Derecho Internacional Privado en América Latina: Liber Amicorum Jürgen Samtleben. Max-Planck-Institut für ausländisches und internationales Privatrecht (Montevideo, Fundación de Cultura Universitaria) pp. 179-189.

León, Avelino (2002b): "Hacia una Reforma del Derecho Aplicable en el Sistema Chileno de Derecho Internacional Privado” en Estudios sobre Reformas al Código Civil y Código de Comercio. Segunda Parte. (Santiago de Chile, Editorial Jurídica de Chile) 488 pp.

Leible, Stefan (2011): "La Importancia de la Autonomía Conflictual para el Futuro del Derecho de los contratos Internacionales", Cuadernos de Derecho Transnacional, vol 3, $\mathrm{n}^{\circ}$ 1, pp. 214-233.

Lira, Pedro (1957): "El Código Civil y su Época” en: Centenario del Código Civil en Chile. Sexto Libro de la Semana de Bello en Caracas (Caracas, Ediciones del Ministerio de Dirección de Cultura y Bellas Artes) pp. 225-242.

López, Jorge (2010): Los Contratos. Parte General (Santiago de Chile, Abeledo Perrot) 5a Ed., 578 pp. 
Vial UndurRaga, María Ignacia — "La autonomía de la voluntad en la legislación chilena de derecho internacional privado"

Loussouarn, Yvon, Bourel, Pierre y De Vareilles-Sommières, Pascal de (2004): Droit International Privé (Paris, Dalloz) $8^{\text {va }}$ Ed., 979 pp.

Lyon, Alberto (2003): Personas Jurídicas (Santiago de Chile, Ediciones Universidad Católica de Chile) 303 pp.

Maluenda, Rodrigo (1998): Contratos Internacionales en el Derecho Chileno (Santiago de Chile, Editorial Jurídica ConoSur) 389 pp.

MaYer, Pierre (2001): Droit International Privé (Paris, Montchrestien) $7^{\mathrm{a}}$ Ed., 729 pp.

Meza, Ramón (1966): Manual de Derecho Civil. De las Fuentes de las Obligaciones (Santiago de Chile, Universidad Católica) $4^{\mathrm{a}}$ Ed., vol. 1, 441 pp.

Nygh, Peter (1999): Autonomy in International Contracts (Oxford, Clarendon) 282 pp.

Plender, Richard y Wilderspin, Michael (2001): The European Contracts Convention (Londres, Sweet \& Maxwell) 2a Ed., 407 pp.

Plender, Richard y Wilderspin, Michael (2009): The European Private International Law

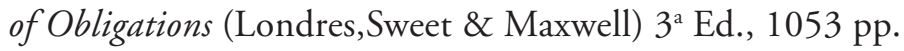

Rabel, Ernst (1947): The Conflict of Laws. A Comparative Study (Chicago, Callaghan) vol. 2, $705 \mathrm{pp}$.

Ramírez, Mario (1965): Síntesis del Derecho Internacional Privado Chileno (Santiago de Chile, Imprenta "El Imparcial") 97 pp.

Ramírez, Mario (1990): Curso de Derecho Internacional Privado Chileno (Santiago de Chile, Editorial ConoSur) 142 pp.

Ramírez, Mario (2010): Curso Básico de Derecho Internacional Privado (Santiago de Chile, Editorial Abeledo Perrot) 196 pp.

Repertorio de Legislación y Jurisprudencia Chilena Repertorio de Legislación y Jurisprudencia Chilena. Código Civil y Leyes Complementarias (Santiago de Chile, 1996) $3^{\text {a }}$ Ed., vol. 1, 511 pp.

RüHL, Giesela (2007): "Party Autonomy in the Private International Law of Contracts: Transatlantic Convergence and Economic Efficiency”, en: Gotтschalk, Eckart, MiChaels, Ralf, Rühl, Giesela, Von Hein, Jan (edit.), Conflict of Laws in a Globalized World (Nueva York, Cambridge University Press) pp. 153-183.

Ruz, Gonzalo (2011a): Explicaciones de Derecho Civil. Parte General y Acto Jurídico (Santiago de Chile, Abeledo Perrot) vol. 1, 552 pp.

Ruz, Gonzalo (2011 b): Explicaciones de Derecho Civil. Contratos y Responsabilidad Extracontractual (Santiago de Chile, Abeledo Perrot) vol. 4, 573 pp.

Samtleben, Jürgen (1983): Derecho Internacional Privado en América Latina. Teoría y Práctica del Código de Bustamante (Traducc. Carlos Bueno-Guzmán, Buenos Aires, Depalma) vol. 1, 399 pp.

Scoles, Eugene, Hay, Peter, Borchers, Patrick y Symeonides, Symeon (2004): Conflict of Laws (St Paul Minnesota, Thomson West) $4^{\mathrm{a}}$ Ed., 1565 pp.

Veloso, Rafael (1931): Derecho Internacional Privado (Santiago de Chile, Nascimento) 142 pp.

Villarroel, Carlos y Villarroel, Gabriel (1988): "Consideraciones sobre el Estatuto Personal en la Legislación Chilena”, Revista Chilena de Derecho, vol. 15: pp. 341-374. 
Villarroel, Carlos y Villarroel, Gabriel (1990): “Determinación de la Ley Aplicable a los Derechos y Obligaciones Emanados de los Contratos Internacionales”, Revista Chilena de Derecho, vol. 17: pp. 351-365.

Villarroel, Carlos y Villarroel, Gabriel (2004): Curso de Derecho Internacional Privado (Santiago de Chile, Editorial Jurídica de Chile) 148 pp.

\section{JURISPRUDENCIA CITADA}

Aerochile Ltda. con Insignia Limited (1997): Corte Suprema, 22-VII-1997, Rol 3928-96 (apelación de recurso de protección) no publicada.

Avila Mardones, Jorge (1989): Corte Suprema, 26-IX-1989 (recurso de queja), Revista de Derecho y Jurisprudencia 86 (1989) $2^{\text {a }}$ parte, sección $1^{\text {a, }}$ pp. 127-128.

Charles Semond y Co. con A. y R. Falabella y Co. (1927): Corte Suprema, 21-XII-1927 (cobro de pesos), GT (1927) No 90, pp. 398-410.

Corte de Apelaciones de Santiago, 31-VIII-2003, no 11.276-2002 (recurso de apelación), no publicada.

Davis, Turner \& Co. con Wolhmuth (1924): Juzgado Civil Santiago, 1924, no publicada, citada por Etcheberry (1960) p. 58 y Albónico (1943) 144 p.

Déliz con Compañia de Seguros Liverpool y otros (1910): Corte Suprema, 9-VIII-1910 (casación en el fondo), Revista de Derecho y Jurisprudencia 7 (1910) 2a parte, sección $1^{\text {a }}$ pp. 342-355.

Duval i Diaz con Laureiro (1906): Corte Suprema 10-VIII-1906 (casación en el fondo), Gaceta de los Tribunales (1906) N 595,vol. I pp. 953-965.

Ferrer con Banco Español de Chile (1931): Corte de Apelaciones de Santiago, 13-I-1931 (recurso de apelación), Gaceta de los Tribunales (1931) Nº 69 pp. 299-327.

Fiscal con Moreno M. Jaime (1999): Corte Suprema, 17-XI-1999 (exequátur), disponible en http://cl.microjuris.com/getContent?reference=MJCH_MJJ249\&links=[MOR,\%20 MELITON,\%20JAIM,\%20MOR,\%20MELITON,\%20JAIM] [fecha de consulta: 10XII-2012].

Hauschild y otra con Urrutia (1957): Corte de Apelaciones de Santiago, 16-III-1957 (arrendamiento), Revista de Derecho y Jurisprudencia 54 (1957) 2a parte, sección 2a pp. 25-29.

Hoffman con Fisco (1911): Corte Suprema, 8-VI-1911 (casación en el fondo), Revista de Derecho y Jurisprudencia 9 (1912) 2a parte, sección $1^{a}$ pp. 358-370.

H. J. Broom y Cía con Exportadora Frutícola Antumalal (1999): Corte Suprema, 25I-1999, disponible en: http://cl.microjuris.com/getContent?reference=MJCH_ MJJ798\&links=[H,\%20J,\%20BROOM] [fecha de consulta: 10-XII-2012].

Jaluff (1943): Corte de Apelaciones de Santiago, 10-IV-1943 (revocación de posesión efectiva), Revista de Derecho y Jurisprudencia 40 (1943) 2a parte, sección $2^{a}$ pp. 44-48.

Martínez con Martínez de Acevedo (1908): Corte Suprema, 30-X-1908 (reconocimiento de hijo natural), Revista de Derecho y Jurisprudencia 6 (1908) 2a parte, sección $1^{a}$ pp. 88-94.

Napias con Dumas (1878): Corte de Apelaciones de Santiago, 14-XII-1878 (cobro de pesos), Gaceta de los Tribunales (1878) No 4674 pp. 1968-1969. 
Vial UndurRaga, María Ignacia — "La autonomía de la voluntad en la legislación chilena de derecho internacional privado"

Pacey con Barroso (1926): Corte de Apelaciones de Santiago, 24-IX-1926 (recurso de apelación), Revista de Derecho y Jurisprudencia 25 (1926) 2a parte, sección $2^{a}$ pp. 49-52.

Prunet con Sociedad Anónima La Industrial (1874): Corte de Apelaciones de Santiago, 12-I1874 (garantía de contrato), Gaceta de los Tribunales (1874) N 123 pp. 66-67.

Ramos con Compañía de Azúcar de Chiclayo (1918): Corte Suprema, 31-X-1918 (casación en el fondo), Revista de Derecho y Jurisprudencia 16 (1918) 2a parte, sección $1^{a}$ pp. 365-405.

Roumié con Pate Perrin (1960): Corte Suprema, 4-IV-1960 (exequátur), Revista de Derecho y Jurisprudencia 57 (1960) 2a parte, sección $1^{\text {a }}$ pp. 46-52.

Sociedad Hauts Fourneaux, Forges et Aciéries du Chili con Conde Armanol y otro (1926): Corte Suprema, 12-XI-1926 (casación en el fondo), Revista de Derecho y Jurisprudencia 24 (1927) $2^{a}$ parte, sección $1^{a}$ pp. 289-408.

Sorucco, Echeverría y Cía. Ltda. con Sorucco, Echeverría Ltda. (1943): Corte Suprema, 20X-1943 (casación en el fondo), Revista de Derecho y Jurisprudencia 41 (1944) 2a parte, sección $1^{a}$ pp. 396-404.

State Street Bank and Trust Company con Inversiones Errázuriz Ltda. y Otros (2007): Corte Suprema, 14-V-2007 (exequátur) disponible en http://www.legalpublishing3.cl/maf/ app/documentVM? rs=\&vr=\&src=search \&docguid $=$ i0ADFAB87B571733981B57944 27CFE91D \&spos $=\&$ epos $=2003 \& \mathrm{td}=\&$ page $=80 \&$ snippets $=$ true $\&$ srguid $=\mathrm{i} 0 \mathrm{ad} 818150$ 000013 b6c9ef8d1f1dfaac2\&openLocator=\&crumb-action=append [fecha de consulta: 7-XII-2012].

Tobar y otros con Fisco (1921): Corte Suprema, 1-VI-1921(casación en el fondo), Revista de Derecho y Jurisprudencia 20 (1921) 2 $2^{\text {a }}$ parte, sección $1^{a}$ pp. 280-301.

Zolezzi y otra con Gallardo (1955): Corte Suprema, 27-VI-1955 (casación en el fondo), Revista de Derecho y Jurisprudencia 52 (1955) 2a parte, sección $1^{a}$ pp. 134-138.

\section{NORMAS CITADAS}

Chile:

Código Civil, publicado 14-XII-1855.

Código de Aeronáutica, Ley 18.916, 19-I-1990, Diario Oficial 8-II-1990.

Código de Comercio, publicado 23-XI-1865.

Código del Trabajo, DFL n 1, 31-VII-2002, Diario Oficial 16-I-2003 y 27-II-2003.

Ley de Arbitraje Comercial Internacional, Ley 19.971, 10-IX-2004, Diario Oficial 29-IX2004.

Ley de Matrimonio Civil, Ley 19.947, 7-V-2004, Diario Oficial 17-V-2004.

Ley de Protección al Consumidor, Ley 19.946, 7-II-1997, Diario Oficial 7-III-1997.

Ley sobre el Efecto Retroactivo de las Leyes, 7-X-1861.

Decreto Ley 2.349, 13-X-1978, Diario Oficial 28-X-1978.

Decreto 374 Ministerio de Relaciones Exteriores, 10-IV-1934, Diario Oficial 25-IV-1934.

Decreto 458 Ministerio de Relaciones Exteriores, 12-VI-1979, Diario Oficial 13-VIII1979.

Decreto 544 Ministerio de Relaciones Exteriores, 31-V-1990, Diario Oficial 3-X-1990. 
Decreto 1.383 Ministerio de Relaciones Exteriores, 27-VIII-1997, Diario Oficial 9-XII1997.

Otros Países:

Código Civil Argentino, Ley 340 del 28-IX-1869.

Código Civil de Luisiana, Libro IV, Luisiana. Acts 1991, № 923.

Código Civil de Quebec, 8-XII-1991.

Código Civil del Uruguay, modificado por Ley 10.084, 25-XI-1941, Diario Oficial 12-XII1941.

Código Civil de la Federación Rusa, Parte Tercera 2001.

Código Civil Federal Mexicano, 29-V-2000, Diario Oficial de la Federación 29-V-2000.

Código Civil Francés, 1804.

Código Civil Peruano, Decreto Legislativo 295, 24-VII-1984, El Peruano 25-VII-1984.

Código Civil para el Distrito Federal, México, 25-V-2000, Gaceta Oficial 25-V-2000.

Einführungsgesetz zum Bürgerlichen Gesetzbuche (EGBGB - Ley Introductoria del Código Civil Alemán) de 18-VIII-1896 (modificada por Ley de 23-V- 2011, Gaceta Federal I p. 898).

Ley Federal de Derecho Internacional Privado Suiza, 18-XII-1987, Recueil Officiel du Droit Fédéral 1776, 1998.

Ley de Derecho Internacional Privado Venezolana, 6-VIII-1998, Gaceta Oficial 6-VIII1998.

Ley Italiana de Derecho Internacional Privado, Ley 218 del 31-V-1995. Gaceta Oficial de la República Italiana 3-VI-1995.

Ley de Introducción al Código Civil Brasileño, Decreto Ley 4.657, 4-IX-1942 Coleção das Leis da República 1942; III 305.

Ley Rumana de Derecho Internacional Privado, 1992.

Reglamento (CE) No 593/2008 del Parlamento Europeo y del Consejo de 17 de junio del 2008 Sobre Ley Aplicable a las Obligaciones Contractuales (Roma I) Official Journal of the European Union L 177, 4-VII-2008.

Uniform Commercial Code, EE.UU, 1991.

\section{TRATADOS INTERNACIONALES CITADOS}

\section{LATINOAMERICANOS:}

Código de Bustamante, La Habana 20-II-1928.

Convención Interamericana de Normas Generales de Derecho Internacional Privado, Montevideo 8-V-1979.

Convención Interamericana sobre la Ley Aplicable a los Contratos Internacionales, Ciudad de México 17-III-1994.

Protocolo de Buenos Aires sobre Jurisdicción Internacional en Materia Contractual, MERCOSUR, 5-VIII-1994. 
No LatinOamericanos:

Convenio de Varsovia para la Unificación de Ciertas Reglas Relativas al Transporte Aéreo Internacional, 12-X-1929.

Protocolo de La Haya, 28-IX-1955.

Protocolo Adicional de Montreal, 25-IX-1975.

Convención de Naciones Unidas sobre los Contratos de Compraventa Internacional de Mercaderías, Viena 11-IV-1980.

CEE Convenio sobre la Ley Aplicable a las Obligaciones Contractuales, Roma 19-VI1980, Official Journal of the European Communities L 277, 9-X-1980.

Convención de La Haya sobre la ley Aplicable a la Compraventa Internacional de Mercaderías, 2-XII-1986. 
